\title{
La responsabilidad de la propia Persona Jurídica en el Derecho Penal peruano e iberoamericano*
}

Dino Carlos Caro Coria

\section{Planteamiento}

La responsabilidad penal de la persona jurídica y de sus órganos ofrece tres aspectos problemáticos: 1) La responsabilidad penal de la propia persona jurídica, en tanto agrupación de personas o corporaciones, hay veces con personalidad jurídica; 2) La responsabilidad penal de los órganos de la persona jurídica en los casos de delitos comunes, lo que nos ubica ante el tema de la delincuencia en el marco de estructuras jerárquicamente organizadas o imputación plurisubjetiva; y, 3) la responsabilidad de los órganos en los casos de delitos especiales, en los que las condiciones, cualidades o relaciones exigidas por el tipo concurren en la persona jurídica, pero no en los órganos que la integran, ámbito en el que se otorga relevancia a la actuación "en lugar de otro" ${ }^{1}$.

En esta contribución interesa poner de relieve, principalmente, los alcances del debate en torno a la responsabilidad penal de la propia persona jurídica, teniendo en cuenta su actual importancia en Derecho penal económico y ambiental. Los otros aspectos configuran problemas de imputación personal, propios de la responsabilidad de las personas naturales, que será abordados de modo accesorio.

1 Silva Sánchez. "Responsabilidad penal de las empresas y de sus órganos en el Derecho español». En: Fundamentos de un sistema curopeo del DP. Barcelona 1995, p. 357 . 


\section{Crisis del societas delinquere non potest}

Puede decirse, en general, que los países iberoamericanos siguen siendo partidarios de la no responsabilidad penal de los entes colectivos. Así se aprecia en textos no recientes como el Código Penal argentino de 1921, el Código Penal mexicano de 1931 para el Distrito Federal en materia de Fuero Común y para toda la República en materia de Fuero Federal ${ }^{2}$, el Código uruguayo de 1933, el Código de Ecuador de 1938, el de Brasil de 1940, el de Venezuela de 1964, el de Costa Rica de 1970, el Código boliviano de $1972^{3}$, el Código chileno de 1975, el Código de Panamá de 1982 o el de Honduras de 1983. De modo similar se expresan textos más actuales como el Código Penal peruano de $1991^{4}$, el Código Penal español de $1995^{5}$, el Código Penal de El Salvador de 1997, el Código Penal paraguayo de 1997 y el Código Penal colombiano de $2000^{6}$.

2 Según el Art. $11^{\circ}$, “Cuando algún miembro o representante de una persona jurídica, o de una sociedad, corporación o empresa de cualquiera clase, con excepción de las instituciones del Estado, cometa un delito con los medios que para tal objeto las mismas entidades le proporcionen de modo que resulte cometido a nombre o bajo el amparo de la representación social o en beneficio de ella, el juez podrá, en los casos exclusivamente especificados por la ley, decretar en la sentencia la suspensión de la agrupación o su disolución, cuando lo estime necesario para la seguridad pública». Con ello se establece un régimen semejante al de las consecuencias accesorias que recogen el CP peruano y el español, Vid. Besares Escobar y otros. DP ambiental. México 2001, p. 82. Antes bien, para Búnster. "Algunas reflexiones en torno a la responsabilidad penal de las personas morales". En: AAVV. La Ciencia Penal en el umbral de siglo $X X I$. Guadalupe 2001 , p. 443, da medidas antedichas no pueden ser sino penas que, si se imponen por el juez, ha de ser previo proceso y de declaración en la sentencia, con las garantías condignas».

3 Ordenado según la Ley No 1768 de 10 de marzo de 1997.

4 L.M. Bramont-Arias Torres, Manual de DP. PG. Lima 2000, pp. 124-125.

5 Berdugo Gómez de la Torre y otros. Lecciones de DP. PG. $2^{\text {a }}$ ed. Barcelona 1999 , pp. 139-140.

6 Bazzani Montoya. "Responsabilidad de las personas jurídicas». En: Cancino/ Bacigalupo. DP Iberoamericano. Bogotá 2001, p. 193 y ss. Se manticne la solución del Código de 1980, Vid. Valencia Iragorri. Delito ecológico. Ibaguć 1996, pp. 22-23. Velásquez Vclásquez. DP. PG. $3^{\mathrm{a}}$ ed. Bogotá 1997, p. 354, n. 74, precisa que el Art. $2^{\circ}$ de la Ley $N^{\circ} 365$ de 1997 introdujo en el Derecho colombiano sanciones penales para las personas jurídicas, «incluso sin probar la comisión de hechos punibles". Antes bien, el Art. $247^{\circ} \mathrm{B}$ del Código de 1980 , introducido por la Ley $N^{\circ} 491$ de 13 de enero de 1999, fue declarado inconstitucional por contcmplar sanciones para la persona jurídica sobre la base de una responsabilidad presunta. 
Sin embargo, de modo excepcional se ha venido adoptando en los últimos años una línea favorable al societas delinquere potest, sobre todo a través de la legislación complementaria. De ese modo, la Ley Penal del Ambiente de Venezuela de 3 de enero de 1992 estableció la posibilidad de imponer penas a los propios entes $\operatorname{colectivos}^{7}$, sin perjuicio de la

7 De los Ríos. Derecho del ambiente. Especial referencia a las disposiciones penales. Caracas 1993, pp. 221-222, para quien las múltiples exigencias previstas en esta ley prácticamente harían imposible sancionar a las personas jurídicas.

$8 \mathrm{Art} .3^{\circ}$.- «Requisitos de las sanciones a personas jurídicas. Independientemente de la responsabilidad de las personas naturales, las personas jurídicas scrán sancionadas de conformidad con lo previsto en la presente ley, en los casos en que el hecho punible descrito de ésta haya sido cometido por decisión de sus órganos, en el ámbito de la actividad propia de la entidad y con recursos sociales y siempre que se perpetre en su interés exclusivo o preferente».

Art. $4^{\circ}$.- "Responsabilidad del representante. Cuando los hechos punibles fucran cometidos por los gerentes administradores o directores de personas jurídicas, actuando a nombre o representación de éstas, aquéllos responderán de acuerdo a su participación culpable y recaerán sobre las personas jurídicas las sanciones que se especifican en esta Ley".

Art. $5^{\circ}$.- «Sanciones a personas naturales. Las sanciones serán principales y accesorias. Las sanciones principales son:

1. La prisión.

2. El arresto.

3. La multa.

4. Los trabajos comunitarios.

La pena de trabajo comunitario consiste en la obligación impuesta al reo de realizar, durante el tiempo de la condena, labores en beneficio de la comunidad, que indicará el juez, quien tendrá presente para tal fin la capacitación de aquél y, en todo caso, sin menoscabo de la dignidad personal.

Esta pena podrá ser impuesta en sustitución de la de arresto en los casos de que el juez lo estimare conveniente, atendidas la personalidad del procesado y la mayor o menor gravedad del hecho.

Son sanciones accesorias, que se aplicarán a juicio del tribunal:

1. La inhabilitación para el ejercicio de funciones o cmpleos públicos, hasta por dos (2) años despućs de cumplirse la pena principal, cuando se trate de hechos punibles cometidos por funcionarios públicos;

2. La inhabilitación para el ejercicio de la profesión, arte o industria, hasta por un (1) año después de cumplida la sanción principal, cuando el delito haya sido cometido por el condenado con abuso de su industria, profesión o arte, o con violación de alguno de los deberes que le sean inherentes;

3. La publicación de la sentencia, a expensas del condenado, en un órgano de prensa de circulación nacional; 
responsabilidad de sus órganos ${ }^{8}{ }^{9}$. A su vez, la Ley brasilera $\mathrm{N}^{\circ} 9.605$ de

4. La obligación de destruir, neutralizar o tratar las sustancias, materiales, instrumentos u objetos fabricados, importados u ofrecidos en venta, y susceptibles de ocasionar daños al ambiente o a la salud de las personas;

5. La suspensión del permiso o autorización con que se hubiese actuado hasta por un lapso de dos (2) años, de cumplida la sanción principal;

6. La suspensión del ejercicio de cargos directivos y de representación en personas jurídicas hasta por tres (3) años, después de cumplida la pena principal; y

7. La prohibición de contratar con la Administración Pública hasta por un lapso de tres (3) años, después de cumplida la sanción principal.

Es necesariamente accesoria a otra pena principal, el comiso de equipos, instrumentos, sustancias u objetos con que se hubiere ejecutado, a no ser que pertenezcan a un tercero ajeno al hecho; y de los efectos de que él provengan.

Los objetos e instrumentos decomisados se venderán, si son de lícito comercio, y su producto se aplicará a cubrir las responsabilidades civiles del penado».

Art. $6^{\circ}$.- "Sanciones a personas jurídicas. La sanción aplicable a las personas jurídicas por los hechos punibles cometidos, en las condiciones señaladas en el articulo $3^{\circ}$ de esta Ley, será la de multa establecida para el respectivo delito, y atendida la gravedad del daño causado, la prohibición por un lapso de tres (3) meses a tres (3) años de la actividad origen de la contaminación.

Si el daño causado fuera gravísimo, además de la multa, la sanción será la clausura de la fábrica o establecimiento o la prohibición definitiva de la actividad de origen de la contaminación, a juicio del juez.

El Tribunal podrá, así mismo, imponer a la persona jurídica, de acuerdo a las circunstancias del hecho que se haya cometido, alguna o algunas de las siguientes sanciones:

1. La publicación de la sentencia a expensas del condenado, en un órgano de prensa de circulación nacional;

2. La obligación de destruir, neutralizar o tratar las sustancias materiales, instrumentos u objetos fabricados, importados u ofrecidos en venta, y susceptibles de ocasionar daños al ambiente o a la salud de las personas;

3. La suspensión del permiso o autorización con que se hubiese actuado, hasta por un lapso de dos (2) años; y

4. La prohibición de contratar con la Administración Pública hasta por un lapso de tres (3) años».

9 Ya el Art. $4^{\circ}$ del Proyecto de Ley de Protección Penal de Ambiente de Venezuela de 1981 había previsto la responsabilidad penal de las personas jurídicas: «Las personas jurídicas serán responsables por las infracciones cometidas a causa del ejercicio de sus actividades o en los casos en que los daños o el peligro de daño provenga de actos realizados en su representación o por orden suya". Según la exposición de motivos del Proyecto "merece especial atención el hecho de considerar como sujetos penales a la persona jurídica, el motivo último que se ha orientado a tal determinación es la necesidad que existe en el país de contrarrestar la agresión al ambiente por medio de las empresas que funcionan con csta característica. La discusión sobre el problema de la 


\section{2 de febrero de $1998^{10}$ sobre sanciones penales y administrativas deri- vadas de conductas o actividades lesivas del medio ambiente ${ }^{11}$ prevé}

persona jurídica y sus relaciones con el derecho penal es larga y concienzuda. Sin embargo, hoy por hoy, es de indudable mérito convencerse del hecho de que quienes con más propiedad pueden transformar el ambiente, para bien o mal del hombre, son corporaciones, debido a que están capacitadas para motorizar grandes proyectos debido a la necesidad de grandes inversiones. La persona jurídica sería responsable de aquellas infracciones que se cometieren a causa del ejercicio de sus actividades o en los casos en que éstas se comentan en representación suya o por su mandato".

10 De Araujo Junior. Integración regional y delitos económicos. Societas delinquere non potest-estado actual. Teorias actuales en el DP. Buenos Aires 1998, p. 539. Ribeiro Lopes. "Responsabilidade penal da pessoa jurídica. As bases de uma nova modalidade de direito sancionadom. En: Revista Ibero-Americana de Ciências Penais. No 1/2000, pp. 169 ss.

11 Art. 2०: "Quem, de qualquer forma, concorre para a prática dos crimes previstos nesta Lei, incide nas penas a estes cominadas, na medida da sua culpabilidade, bem como o diretor, o administrador, o membro de conselho e de órgão técnico, o auditor, o gerente, o preposto ou mandatário de pessoa jurídica, que, sabendo da conduta criminosa de outrem, deixar de impedir a sua prática, quando podia agiv para evitála".

Art. 3०: "As pessoas juridicas seräo responsabilizadas administrativa, civil e penalmente conforme o disposto nesta Lei, nos casos em que a infraçăo seja cometida por decisão de seu representante legal ou contratual, ou de seu órgäo colegiado, no interesse ou beneficio da sua entidade.

Parágrafo unico: A responsabilidade das pessoas juridicas não exclui a das pessoas fisicas, autoras, co-autoras ou partícipes do mesmo fato".

Art. $4^{\circ}$ : "Poderá ser desconsiderada a pessoa juridica sempre que sua personalidade for obstáculo ao ressarcimento de prejuizos causados à qualidade do meio ambienten.

Art. $21^{\circ}$ : "As penas aplicâveis isolada, cumulativa ou alternativamente às pessoas juridicas, de acordo com o disposto no art. $3^{\circ}$., sāo:

I.- multa;

II. - restritivas de direitos;

III. prestação de serviços à comunidade».

Art. $22^{\circ}$ : "As penas restritivas de diveitos da pessoa juridica săo:

I. suspensão parcial ou total de atividades;

II. interdição temporária de estabelecimento, obra ou atividade;

1Il. proibição de contuatar com o Poder Público, bem com dele obter subsidios, subvençôes on doaçöes.

$\$ 1 .{ }^{\circ}$ A suspensăo de atividades será aplicada quando estas näo estiverem obedecendo às disposiçôes legais ou regulamentares, relativas à proteçăo do meio ambiente.

$\$ 2 .^{\circ}$ A interdiçäo será aplicada quando o estabelecimento, obra ou atividade estiver funcionando sem a devida autorizaçāo, ou em desacordo com a concedida, ou com visolação de disposiçāo legal ou regulamentar. 
penas para las personas jurídicas. En Argentina, esta forma de responsabilidad se ha planteado en el análisis del Código Aduanero, en la Ley de Defensa de la Competencia, en la Ley de Abastecimiento, en la Ley sobre el Régimen Penal Cambiario, en la Ley Penal Tributaria, entre otras que prevén sanciones de multa e inhabilitación, pérdida de la personería o caducidad de prerrogativas acordadas ${ }^{12}$. En un contexto más general, el Art. $16^{\circ}$ del CP cubano de 1987, reformado en $1997^{13}$, admite la responsabilidad penal de las entidades colectivas ${ }^{14}$, al igual que el Código Penal del Estado mexicano de Tabasco ${ }^{15}$.

En el plano prelegislativo, aunque la Ley argentina No 24.051 de Residuos Peligrosos sólo reconoce la criminalización de los actos de los órganos de dirección de las personas jurídicas en el delito de contamina-

$\$ 3 .^{\circ}$ A proibição de contratar com o Poder Público e dele obter obter subsidios, subvençōes ou doaçōes não poderá exceder o prazo de 10 (dez) anos".

Art. 23": "A prestaçẫo de serviços à comunidade pela pessoa juridica consistirá em:

I. custeio de programas e de projetos ambientais;

II. execução de obras de recuperação de áreas degradadas;

III. manutenção de espaços públicos;

$I V$ contribuiçoes a entidades ambientais ou culturais públicas».

Art. 24: "A pessoa juridica constituida ou utilizada, preponderantemente, com o fim de permitir, facilitar ou ocultar a prática de crime definido nesta Lei terá decretada sua liquidaçăo forģada, seu patrimônio será considerado instrumento do crime e como tal perdido em favor do Fundo Penitenciário Nacional».

12 Fellini. «Problemas de imputación penal en el ámbito de las personas jurídicas». En: AAVV. La Ciencia Penal en el umbral de siglo XXI, op. cit., pp. 433-434.

13 Por el Art. $3^{\circ}$ del D. Ley No 175 de 17 de junio de 1997.

14 Art. 16\%: "1. La responsabilidad penal es exigible a las personas naturales y las personas jurídicas. [...]

3. Las personas jurídicas son penalmente responsables por los delitos previstos en este Código o en leyes especiales, cometidos dentro de la propia esfera de acción de dichas personas jurídicas, cuando sean perpetrados por su representación o por acuerdo de sus asociados, sin perjuicio de la responsabilidad penal individual en que hayan incurrido los autores o cómplices en el hecho punible.

4. A los efectos de este Código, le es exigible responsabilidad penal a las personas jurídicas cuando se trate de las cooperativas, las sociedades y asociaciones constituidas de conformidad con los requisitos establecidos en las leyes, las fundaciones, las empresas no estatales autorizadas para realizar sus actividades, así como las demás entidades no estatales a las que la ley confiere personalidad juridica".

15 Búnster. "Algunas reflexiones en torno a la responsabilidad penal de las personas morales", cit., pp. $443-445$. 
ción $^{16}$, y prima en general el societas delinquere non potest ${ }^{17}$, ello no ha impedido planteamientos en sentido contrario, favorables a la responsabilidad de dichas entidades ${ }^{18}$, perspectiva a la que obedecen el Art. $9^{\circ}$ del Proyecto de 8 de junio de 1988 presentado por los diputados Orosia Botella y Oscar Fappiano ${ }^{19}$, el Art. $10^{\circ}$ del Proyecto del Poder Ejecutivo de 1991 de reforma del Código Penal ${ }^{20}$, y el Art. $11^{\circ}$ del Proyecto de 30 de setiembre de 1992 sancionado por el Senado ${ }^{21}$.

16 Art. $57^{\circ}$.- "Cuando alguno de los hechos previstos en los dos artículos anteriores se hubiesen producido por decisión de una persona jurídica, la pena se aplicará a los directores, gerentes, síndicos, miembros del consejo de vigilancia, administradores, mandatarios o representantes de la misma que hubiesen intervenido en el hecho punible, sin perjuicio de las demás responsabilidades penales que pudiesen existir».

17 Libster. Delitos ecológicos. Buenos Aires 1993, p. 210.

18 Rusconi. "Algunas cuestiones referidas a la técnica legislativa del delito ecológico". En: Maier. Delitos no convencionales. Buenos Aires 1994, pp. 181ss.

19 En: Ambiente y Recursos Naturales 4/1988, pp. 54-56. El Art. $9^{\circ}$ propone modificar el CP: «Incorpórase como artículo $208^{\circ}$ (noveno) d siguiente: Las personas jurídicas o entidades de existencia ideal, son solidariamente responsables del cumplimiento de las penas de multa impuestas por la comisión de delitos previstos en el presente capítulo por el que actuare voluntario, gerentes técnicos o funcionarios de jerarquía equivalente o cuando el autor o autores se encontraren bajo su dependencia y el delito haya sido cometido con motivo o en ocasión de sus funciones". A su vez, la exposición de motivos señala: "Ello se encadena con la solidaridad prevista en el artículo $208^{\circ}$ (noveno) para la persona jurídica en cuanto al cumplimiento de las penas pecuniarias impuestas a sus directivos, con el propósito solidario, entendemos, produce una mayor presión, necesaria para la evitación de este tipo de delitos".

20 En: Libster. Delitos ecológicos, op. cit., pp. 193-196. El Art. $10^{\circ}$ precisa: "Incorpórase como artículo $208^{\circ}$ décimo el siguiente: Las personas jurídicas o entidades de existencia ideal son solidariamente responsables del cumplimiento de las penas de multa impuestas por la comisión de delitos previstos en el presente capítulo por el que actuare como directivo, órgano, representante legal o voluntario, gerentes técnicos o funcionarios técnicos de jerarquía equivalente o cuando el autor o autores se encontraren bajo su dependencia y el delito haya sido cometido con motivo o en ocasión de sus funciones".

21 Tarrio/Muraca. “El Derecho ambiental y los delitos ecológicos». En: Maier. Delitos no convencionales, op. cit., pp. 201-204. El Art. $11^{\circ}$ precisa: "Incorpórase como artículo $208^{\circ}$ undecies el siguiente: Será reprimido con la misma pena del delito de que se trate quienes tuvieren a su cargo la dirección, administración, gerencia general, gerentes técnicos ofuncionarios de categoría equivalente, que hubieren determinado la realización del hecho punible. Asimismo, las personas jurídicas son solidariamente responsables del cumplimiento de penas de multa”. 
En la misma dirección se inscribió el Proyecto de Código Penal de Guatemala de 1991, cuyo Título VII de la Parte General se orientó a establecer los criterios de imputación de «Responsabilidad penal de las personas jurídicas» $\left(\text { arts. } 46^{\circ}-56^{\circ}\right)^{22}$. Recientemente, el Art. $27^{\circ}$ del

22 Art $46^{\circ}$. "Ilicitud especial. Serán imputables a las personas jurídicas los delitos previstos en los Títulos V, VI, VII, VIII, IX, X, XII, XIII, XIX, y XX, capítulo 2, de la Primera Parte del Libro Segundo y las faltas del título VI de la Segunda Parte del mismo libro, cuando se tratare de actos realizados por sus órganos regulares, siempre que se hallaren dentro del giro u objeto normal o aparente de sus negocios.

También será imputable la omisión de un acto, cuando la persona jurídica estuviere legalmente obligada a hacerlo, hubiere aceptado formalmente ese deber, o dicha obligación surgiere de un acto ilícito precedente de esa misma persona o de otra vinculada a ella".

Art. $47^{\circ}$. "Responsabilidad de los representantes. Las personas físicas que actuaron como órganos de la persona jurídica serán también responsables de los actos u omisiones atribuibles a su representado, según las reglas generales previstas para la ilicitud de las personas físicas.

Si la ilicitud o su agravación depende de calidades personales, que posee la persona jurídica, ella se aplicará a quienes de algún modo participaron en la realización de los actos u omisiones y conocían estas calidades personales, aun cuando ellos no las posean.

En todos los casos, la responsabilidad de las personas físicas o jurídicas es independiente, sin perjuicio de las reglas de participación criminal”.

Art. $48^{\circ}$. "Remisión. Las reglas previstas en los títulos II y IV de este Libro, serán aplicables a los delitos y faltas cometidos por personas jurídicas, siempre que sean compatibles con la norma de imputación prevista en el art. 46".

Art. $49^{\circ}$. "Penas. Las penas previstas en este código para las personas jurídicas son las siguientes, en orden de gravedad:

Cancelación de la personalidad jurídica;

Multa;

Suspensión total o parcial de actividades;

Pérdida de beneficios estatales;

Prestaciones obligatorias;

La publicidad de la sentencia condenatoriaw.

Art. $50^{\circ}$. "Cancelación de la personalidad jurídica. Se podrá cancelar la personalidad jurídica, sin perjuicio de la aplicación de las otras penas compatibles, siempre que la escala penal aplicable al caso prevea una penal de prisión mínima mayor de dos años, o un máximo superior a los cinco años, cuando la gravedad del hecho o la reiteración de hechos punibles indiquen que la empresa interviene fundamentalmente en los negocios mediante prácticas delictivas.

La cancelación de la personalidad jurídica implica la extinción de la persona y la liquidación de sus bienes, sin perjuicio de la ejecución de las otras penas impuestas.

La reparación del daño causado por el delito tendrá preferencia sobre cualquier otra deuda. 
Anteproyecto de Código Penal del Estado mexicano de Sinaloa de 2001 plantea, entre las reglas de "Autoría y participación", una cláusula general de responsabilidad de los entes jurídicos colectivos, además de la relativa a la «actuación en lugar de otro» en el Art. $28^{\circ}$, fijando «conse-

Para el procedimiento de liquidación se aplicarán, análogamente, las reglas de la quiebra».

Art. $51^{\circ}$. "Multa. Se aplicará la pena de multa siempre que el delito o falta la prevean expresamente, o cuando tengan prevista pena de prisión; en ese último caso, la pena de prisión se convertirá a razón de una unidad de multa por día de prisión. Si el delito o falta estuviere penado, alternativa o conjuntamente, con pena de prisión y multa, se aplicará únicamente la cantidad de unidades de multa que resulte de la conversión de la pena de prisión, hasta el límite del máximo legal; que en este caso será de 20.000 unidades.

El valor mínimo de la unidad de multa aplicable a las personas jurídicas será de cien quetzales (Q. 100) y el valor máximo de mil quetzales (Q. 1000). La Corte Suprema actualizará anualmente el valor máximo de cada unidad y remitirá el proyecto de ley al Congreso de la República para su aprobación».

Art. $52^{\circ}$. "Suspensión total o parcial de actividades. Se podrá suspender total o parcialmente las actividades de una persona jurídica, sin perjuicio de la aplicación de las otras penas, siempre que el delito importe el abuso de una posición dominante en el mercado, o el abuso o la desnaturalización del objeto de la persona jurídica.

La suspensión total implica la paralización de toda actividad, salvo aquellas imprescindibles para mantener el giro básico de los negocios, la continuidad de la empresa o el mantenimiento de las fuentes de trabajo.

El tribunal determinará la actividad de la que se debe prescindir en caso de suspensión parcial de las actividades.

Durante la suspensión total o parcial, los órganos de las personas jurídicas actuarán bajo el control de la persona que determine el Tribunal, quien informará periódicamente sobre el cumplimiento de la pena.

Para determinar la duración de la suspensión de actividades se utilizarán las escalas de la penal de prisión, previstas para cada delito».

Art. $53^{\circ}$. "Pérdida de beneficios estatales. La pérdida de beneficios estatales consiste en la pérdida de subsidios, beneficios fiscales, concesiones, créditos u otras facilidades para la importación y exportación o cualquier otro beneficio o privilegio que hubicre concedido el Estado a alguna persona jurídica.

Esta pena se aplicará, además de las penas previstas, siempre que el delito o la falta implique abuso de esos privilegios o la desnaturalización de los fines para los cuales fueron concedidos".

Art. $54^{\circ}$. "Prestaciones obligatorias. Siempre que el delito o la falta cometida por una persona jurídica hubiere implicado el daño a un bien o interés colectivo, el tribunal, además de las penas previstas, podrá establecer actividades o prestaciones de bien público, orientadas a la reparación del daño provocado por el delito o falta, o a la reposición de las cosas al estado anterior o al querido por la ley, que la persona jurídica deberá realizar obligatoriamente. 
cuencias" para las personas jurídicas entre los arts. $94^{\circ}$ al $99^{\circ 23}$. Asimismo, en el marco de las Sesiones de la Comisión Redactora del Código

El tribunal determinará las modalidades concretas de su ejecución, pero ellas no podrán durar más de dos años. Podrá establecer el pago condicional de una cantidad de dinero por cada día de atraso en el cumplimiento de la actividad impuesta. Los representantes de la persona jurídica son solidariamente responsables del pago de las sumas de dinero impuestas como garantía del cumplimiento de las prestaciones".

Art. $55^{\circ}$. «Publicidad de la sentencia condenatoria. La sentencia que cancele la personalidad jurídica o suspenda la actividad de la empresa, o en los demás casos, cuando la multa supere las trescientas unidades de multa, será publicada o difundida a través de algún medio masivo de comunicación, a costa de la persona jurídica condenada.

El tribunal determinará el medio de difusión".

Art. $56^{\circ}$. "Individualización. En el caso de delitos o faltas cometidas por personas jurídicas, además de las circunstancias relativas a la gravedad del hecho, se tendrá en cuenta el tiempo de existencia de la persona jurídica, su solvencia y prestigio social, el conjunto de sus actividades y negocios, así como la conducta regular de sus representantes.

Medidas de seguridad y corrección. Cuando la reiteración de los delitos o faltas hicicre presumir fundadamente la continuación de las prácticas delictivas o pusiere en peligros el interés público sobre la buena fe en los negocios, la persona jurídica, además de las penas podrá ser sometida a las medidas de seguridad siguientes:

- la creación de un consejo de vigilancia especial determinado por el tribunal;

- la auditoría periódica de las actividades de la persona jurídica;

- la obligación de presentar estados contables en plazos que fijará el tribunal;

- la obligación de requerir autorización judicial para la realización de actos particulares;

En todos los casos, la persona jurídica se deberá hacer cargo de los gastos necesarios para la ejecución de esas medidas.

Las medidas de seguridad y corrección no podrán durar más de cinco años, salvo que las mismas personas que abusaron de sus funciones como órganos de la persona jurídica continuaren en su cargo; en este último caso, la medida de seguridad continuará mientras esas personas permanezcan en funciones, hasta un plazo máximo de diez años".

23 Art. $27^{\circ}$. "Para los efectos de cste código, sólo pueden ser penalmente responsables las personas físicas.

No obstante, cuando algún miembro o representante de una persona o ente jurídicos colectivos, con excepción de las cntidades del Estado o municipios, cometa algún delito con los medios que para tal objeto la misma entidad le proporción, de modo que resulte comerido a nombre, bajo el amparo o en beneficio de ésta, d juzgador impondrá en la sentencia, con audiencia c intervención del representante legal, las consecuencias previstas por este código para las personas o entes jurídicos colectivos, sin perjuicio de la responsabilidad en que hubieren incurrido las personas físicas.

La responsabilidad penal no trascenderá a personas distintas de los sujetos activos ni afectará bienes que no sean de éstos». 
Penal Tipo para Iberoamérica, se ha puesto en discusión una serie de propuestas en torno a los criterios de imputación de responsabilidad de la propia persona jurídica y, como complemento, de la fórmula de la actuación en lugar de otro ${ }^{24}$.

Art. $28^{\circ}$. «El que actuare como directivo u órgano de una persona o ente jurídicos colectivos, o en nombre o representación legal o voluntaria de otro, responderá personalmente, aunque no concurran en él las condiciones, cualidades o relaciones que la correspondiente figura de delito requiera para poder ser sujeto activo del mismo, cuando tales circunstancias se dieren en la persona o ente jurídicos colectivos en cuyo nombre o representación obrare».

Art. 94\%. "A las personas o entes jurídicos colectivos que se les impute responsabilidad en los casos previstos por este código, la autoridad judicial les impondrá en la sentencia alguna de las siguientes consecuencias jurídicas:

I. Prohibición de realizar determinados negocios u operaciones;

II. Intervención;

III. Suspensión; y,

IV. Disolución".

Art. 95\%. "La prohibición de realizar determinados negocios u operaciones podrá ser hasta por cinco años. Se referirá exclusivamente a las que determine el juzgador y deberá tener relación directa con el delito cometido".

Art. 96. "Los administradores y el comisario de la sociedad serán responsables ante la autoridad ejecutora de las consecuencias jurídicas del delito del cumplimiento de la prohibición. En caso de incumplimiento, incurrirán en las penas que establece este código por desobediencia a un mandato legítimo de autoridad".

Art. 97\%. "La intervención consiste en la remoción de sus cargos de los administradores de las personas o entes jurídicos colectivos, encargando sus funciones temporalmente a uno o varios interventores, los cuales serán designados por la autoridad ejecutora de las consecuencias jurídicas del delito una vez que la sentencia haya causado ejecutoria. La intervención cesará cuando los órganos de las personas o entes jurídicos colectivos sustituyan, conforme a los estatutos, a quienes hayan realizado el delito".

Art. 98 . "La suspensión, que no podrá exceder de dos años, consistirá en la cesación de la actividad de la persona o ente jurídico colectivo durante el tiempo que determine la autoridad judicial en la sentencia".

Art. $99^{\circ}$. "La disolución consistirá en la conclusión definitiva de toda actividad de las personas o entes jurídicos colectivos, los que no podrán volverse a constituir por las mismas personas en forma real o encubierta. La conclusión de toda actividad se hará sin perjuicio de la realización de los actos necesarios para la liquidación total. En el caso de la disolución, la autoridad ejecutora de las consecuencias jurídicas del delito, designará liquidador que procederá a cumplir todas las obligaciones contraídas hasta entonces por la persona o ente jurídicos colectivos, inclusive las responsabilidades derivadas del delito cometido, obscrvando, en lo conducente, las disposiciones de la ley de la materia".

24 Vid. infra V. 
Estas expresiones de lege lata y de lege ferenda representan una clara vis expansiva del reconocimiento legal de la responsabilidad penal de los entes colectivos en Iberoamérica, tendencia no aislada si se tiene en cuenta la larga experiencia criminalizadora en los sistemas anglosajones ${ }^{25}$, especialmente en Inglaterra, Irlanda, Estados Unidos ${ }^{26}$, Australia y Canadá, así como en aquellos ordenamientos influenciados por el modelo norteamericano, como Japón y Corea $^{27}$.

A su vez, en los estados de la Unión Europea, ya sólo España, Italia ${ }^{28}$, Alemania y Grecia mantienen reticencias frente a la posibilidad de sancionar penalmente a la persona jurídica ${ }^{29}$. En Europa continental se reconoce claramente el societas delinquere potest en Holanda (art. $51^{\circ}$ del $\mathrm{CP})^{30}$, Noruega (arts. 48a y $48 \mathrm{~b}$ del CP) $)^{31}$, Francia ${ }^{32}$ y Dinamarca ${ }^{33}$. En todo caso, se prevé una próxima armonización al respecto, porque el Art. $14^{\circ}$ del Corpus Iuris de Disposiciones Penales para la Protección de los Intereses Financieros de la Unión Europea ${ }^{34}$, cuya redacción se ulti-

25 Fletcher. Conceptos básicos de DP. Valencia 1997, pp. 292-295.

26 Malamud Goti. Persona juridica y penalidad. Buenos Aires 1981, pp. $145 s$.

27 Feijóo Sánchez. "La responsabilidad penal de las personas jurídicas, ¿un medio cficaz de protección del medio ambiente?n. En: RPCP 9/2000, p. 241.

28 Flora. "Liattualitì del principio "societas delinquere non potest" ". En: RTDPDE 1/ 1995, pp. 11 ss. Militello. "La responsabilidad penal en los grupos de empresas: la experiencia italiana». En: Martínez-Buján Pérez. I Congreso hispano-italiano de DP económico. Da Coruña 1998, pp. 27ss.

29 Tiedemann. «Prólogo». En: Zúñiga Rodríguez. Bases para un modelo de imputación de responsabilidad penal a las personas jurídicas. Pamplona 2000, p. 15.

30 De Doelder. «La punibilidad de las personas jurídicas en Holanda». En: Hacia un DPeconómico europeo. Madrid 1995, pp. 497ss. Vervaele. "La responsabilidad penal de y en el seno de la persona jurídica en Holanda. Matrimonio entre pragmatismo y dogmática jurídica». En: RDPC 1/1998, pp. 153ss.

31 Rostad. "Las multas a las personas jurídicas. Breve esbozo del sistema noruego". En: Hacia un DP económico europeo. Madrid 1995, p. 519 y ss.

32 Pradel. "La responsabilidad penal de las personas jurídicas en el Derecho francés: algunas cuestiones». En: RDPC 4/1999, p. 661 y ss.

33 Feijóo. «La responsabilidad penal de las personas jurídicas", op. cit., pp. 241 243.

34 Art. 140: "1. Serán igualmente responsables de las infracciones definidas con anterioridad (arts. $1^{\circ}$ a $8^{\circ}$ ) las entidades colectivas que tuvieran personalidad jurídica, así como las que tuvieran la calidad de sujeto de derecho y sean titulares de un patrimonio autónomo, cuando la infracción hubiera sido realizada por cuenta del ente colectivo, por un órgano, un representante o cualquier persona que hubiera actuado en nombre propio o con un poder de decisión de derecho o de hecho. 
mó en junio de 1996, establece la responsabilidad penal de las personas jurídicas ${ }^{35}$, medida ante la cual únicamente Grecia e Italia ofrecen problemas de implementación desde la perspectiva constitucional ${ }^{36}$.

Los diferentes organismos vinculados al desarrollo del Derecho penal tampoco han sido inmunes a estas tendencias, ya en 1977 el Consejo de Europa, mediante la Resolución (77) 28 acerca de la contribución del Derecho penal en la protección del ambiente recomendó «un reexamen de los principios de responsabilidad penal, en particular, con el fin de poder introducir en ciertos casos la responsabilidad de las personas jurídicas, privadas o públicas ${ }^{37}$. Dicha perspectiva fue ratificada por el Comité de Ministros de Estados Miembros del Consejo de Europa, mediante la Recomendación R (81) sobre la criminalidad en los negocios de 25 de junio de 1981, la Recomendación R (82) 15 sobre el papel del Derecho penal en la protección de los consumidores de 24 de setiembre de 1982 y en la Recomendación No 18/88 de 20 de octubre de 1988 , la cual propone "la aplicación de la responsabilidad y de sanciones penales a las empresas cuando la naturaleza de la infracción, la gravedad de la culpabilidad de la empresa y la necesidad de prevenir otras infracciones así lo exijan».

De modo similar, en el XII Congreso Internacional de Derecho Penal celebrado en Hamburgo en 1979 se concluyó que "como los ataques graves al ambiente son comúnmente cometidos por personas jurídicas y empresas privadas, debe admitirse la responsabilidad penal de éstas o imponerles el respeto del ambiente mediante sanciones civiles o administrativas ${ }^{38}$. En una perspectiva más general, en el XIII Congreso Internacional de Derecho Penal celebrado en El Cairo en 1984 se puso de relieve que «la responsabilidad penal de las sociedades u otras entidades jurídicas se reconoce en un número creciente de países como medio apropiado de controlar los delitos económicos y empresariales. Los paí-

2. La responsabilidad penal de las entidades colectivas no excluirá la de las personas físicas, autores, inductores o cómplices de los mismos hechos"

35 AAVV. Hacia un espacio judicial europeo. Corpus Iuris de disposiciones penales para la protección de los intereses financieros de la Unión Europea. Madrid 1998, p. 52.

36 Delmas-Marty/Vervacle. The implementation of the Corpus Iuris in the member states. Vol. I. Utrecht 2000, p. 259. Vid. ampliamente los reportes nacionales en los Vols. II y III.

37 Recomendación 2.

38 Sección II, Recomendación 7. 
ses que no reconocen tal responsabilidad penal deberán considerar la posibilidad de imponer otras medidas apropiadas a estas entidades jurídicas" ${ }^{39}$. A su vez, con sumo carácter extensivo, en el XV Congreso Internacional de Derecho Penal celebrado en Río de Janeiro en 1994 se recomendó a los estados establecer la responsabilidad penal de las personas jurídicas privadas y de Derecho público frente a los ataques contra el ambiente natural ${ }^{40}$.

39 Sección II, Recomendación 16.

40 Sección I/ «III. Responsabilidad penal de las personas jurídicas por infracciones penales contra el ambiente

12. Las conductas merecedoras de la imposición de sanciones penales pueden ser realizados tanto por personas físicas como por personas jurídicas y organismos públicos.

13. Los sistemas jurídicos nacionales deberían prever, si fuera posible en su Constitución o Derecho fundamental, una amplia variedad de sanciones penales y otras medidas adaptadas a las personas jurídicas y organismos públicos.

14. Cuando una persona jurídica, de Derecho público o privado, se encuentre involucrada en una actividad que plantea un serio riesgo de daño para el ambiente, debería obligarse a los directivos y a las autoridades gestoras de esos organismos a que ejerzan su responsabilidad de control para prevenir la producción del daño; y deberían ser considerados penalmente responsables si se produce el daño como consecuencia de su fracaso en cl adecuado cumplimiento de su responsabilidad de control.

15. Para minimizar el riesgo de injusticia procedente de la inadecuada aplicación de leyes relativas a las infracciones contra el ambiente, el derecho doméstico debería especificar lo más claramente posible los criterios de identificación de los agentes humanos intervinientes en el marco de las personas jurídicas de derecho público o de derecho privado potencialmente declaradas responsables de infracciones contra el ambiente.

Personas jurídicas privadas

16. En la medida en que sea posible de acuerdo con la Constitución o las leyes fundamentales del país y sin perjuicio del respeto del principio de personalidad de las infracciones penales, debería ser posible la persecución de personas jurídicas privadas por infracciones penales contra el ambiente si no cabe atribuir directamente esa responsabilidad a un agente humano identificado de la cntidad.

17. En las mismas condiciones, cuando una persona jurídica privada sea responsable de grave daño contra el ambiente, debería poder perscguirse a esa entidad por infracciones contra el ambiente, con independencia de si el daño resulta de un acto u omisión individual o de actos u omisiones acumulados a lo largo del tiempo.

18. La imposición de sanciones penales contra personas jurídicas privadas no debería servir de vía de exoneración de los culpables pertenecientes a las entidades involucradas en la comisión de infracciones contra el ambiente.

Personas jurídicas de Derecho público

19. Cuando en el curso del cumplimiento de su función pública, o en cualquier ot ra circunstancia, un organismo de Derecho público causa un grave daño al ambiente 
Como puede observarse, la responsabilidad penal de los entes colectivos es una concreta y creciente realidad en el Derecho comparado ${ }^{41}$. Frente a ello merece prestar atención a los fundamentos de esta forma de expansión del Derecho penal.

\section{Revisión de los principales fundamentos de la «irresponsabilidad penal de las personas jurídicas»}

Es lugar común señalar que la irresponsabilidad penal de los entes colectivos fluye del estado actual de la dogmática, conclusión inevitable si se parte del modelo de imputación creado para las personas físicas. Por esa vía, la irresponsabilidad terminaría derivando de la propia naturaleza de la persona jurídica. La ausencia de una voluntad óntica o sicológica, y la imposibilidad de actuación por sí misma, sino a través de sus representantes, impedirían que estas entidades puedan configurar los presupuestos dogmáticos necesarios para afirmar la existencia de un hecho punible que pueda atribuírseles ${ }^{42}$.

A partir de estas premisas se ha sostenido que no debería admitirse la punición de los entes colectivos, principalmente porque: 1) no realizan

o, en contravención de los standard ambientales establecidos, crea un peligro real o inminente (concreto) para el ambiente o para los seres humanos, debería poder perscguirse a esa persona por tal infracción.

20. Siempre que sea posible conforme a la Constitución o el derecho nacional de una país la atribución de responsabilidad a los organismos de Derecho público por actos de servicio público u otros, debería admitirse la persecución incluso si la responsabilidad por el delito concreto no puede ser directamente imputada a ninguna persona física determinada o agente de la entidad".

41 Como precisa Muñoz Conde. "Cuestiones dogmáticas básicas en los delitos cconómicos". En: Revista Penal 1/1997, p. 72, "No estamos hablando de "cienciaficción” jurídica, sino de concretas realidades en muchos ordenamientos". Por ello no se comprenden opiniones tajantes, al margen de la realidad legislativa y de las elaboraciones dogmáticas, como la de Castillo Alva. "Apuntes sobre la responsabilidad penal de las empresas y las personas jurídicas". En: Normas Legales T. 276/1999, p. A-55, cuando concluye que "En el Derecho Penal contemporánco la responsabilidad penal de las personas jurídicas y la empresa es más una aspiración lejana que un programa inmediato viable».

42 Caro Coria. "La irresponsabilidad penal de la persona juridica". En: Thémis $24 /$ 1992, p. 71. 
una acción penalmente relevante; 2) por la imposibilidad de realizar el juicio de atribución subjetiva o de culpabilidad; $y, 3$ ) ante la imposibilidad de aplicar a las personas jurídicas las penas previstas para las personas naturales ${ }^{43}$. Se han planteado otros argumentos menos decisivos como la violación del principio de personalidad de las penas, porque se pueden ver afectadas personas inocentes, así como problemas vinculados a la capacidad de pena ${ }^{44}$.

Pero como precisa García Arán, ante estas y otras dificultades, caben dos opciones opuestas, la resignación descriptiva porque no se puede incluir a las personas jurídicas en las categorías subjetivas que maneja el Derecho penal, o la imputación de responsabilidad mediante técnicas diferentes a las de las personas físicas ${ }^{45}$. Ambas direcciones se analizan a continuación.

\subsection{Sobre la capacidad de conducta de las personas jurídicas}

Tanto si se parte de una concepción causal o final de acción, puede sostenerse que la persona jurídica carece de la aptitud interna necesaria para formar una "voluntad propia" al margen de la voluntad expresada por sus integrantes. En esa línea de ideas, parece inevitable aceptar que el ente colectivo no puede exteriorizar la voluntad social construida sobre el conjunto de voluntades individuales, sino a través de los actos de los propios componentes de la agrupación. A su vez, si se toma en cuenta el concepto social de acción tampoco se arribaría a resultados satisfactorios por situarse en el plano extrajurídico. De ese modo, las personas jurídicas no podrían ser objeto de la norma de determinación sino sólo de la norma de valoración ${ }^{46}$.

Pero la revisión de estas conclusiones, en orden a erigir la responsabilidad penal de la persona moral, se ha orientado en una triple dirección que escapa en todo caso al circulo vicioso generado por la inocua pre-

43 Serrano-Piedecasas Fernández. “Sobre la irresponsabilidad penal de las personas juridicas». En: Thémis 35/1997, p. 130.

44 Feijóo. "La responsabilidad penal de las personas jurídicas», op. cit., p. 238.

45 García Arán. "Algunas consideraciones sobre la responsabilidad penal de las personas jurídicas». En: Martínez-Buján Pérez. I Congreso hispano-italiano de DP económico, op. cit, p. 46.

46 Gracia Martín. "La responsabilidad penal de las propias personas jurídicas". En: ADPCP 1993, pp. 603-604. 
tensión de atribuir capacidad de acción a la persona jurídica exigiendo de ella una voluntad sicológica.

Un primer lineamiento se concreta en la revisión del concepto de acción penalmente relevante de modo que abarque, indistintamente, el comportamiento de la persona humana y el del ente colectivo. En esa perspectiva se ubican los planteamientos del funcionalismo normativista, Jakobs entiende que no se trata únicamente de imputar una acción a un sujeto, sino que el concepto de acción define a su vez al sujeto, la acción se define como la evitabilidad individual de la producción de un resultado, o sea la capacidad subjetiva de evitar lo prohibido o realizar lo prescrito $^{47}$.

En ese sentido, no cabe fundamentar que en la definición del sujeto el sistema que ha de erigirse deba componerse siempre de los ingredientes de una persona física (mente y cuerpo) y no de los de una persona jurídica (estatutos y órganos), más bien los estatutos y los órganos de una persona jurídica se pueden definir también como sistema, en el cual lo interno no interesa pero sí el out put, es decir que las actuaciones de los órganos con arreglo a sus estatutos se convierten en acciones propias de la persona jurídica ${ }^{48}$.

Pero si bien debe reconocerse que la acción debe concebirse en términos normativos a fin de evitar una vinculación del deber ser (la determinación del comportamiento penalmente relevante) a las estructuras lógico-objetivas, aún no está claro en la doctrina si de ello debe deducirse una normativización absoluta del concepto de acción que, en buena cuenta, expresa la defensa de la vigencia de la norma como misión del Derecho penal ${ }^{49}$, aspecto que en el estado actual genera controversias no resueltas ${ }^{50}$.

La segunda orientación apunta a crear un concepto de acción distinto y privativo para la persona jurídica, se ha sostenido que la acción de

47 Jakobs. Strafrecht. AT. 2a ed. Berlin/New York 1991, 6/1, 6/26.

48 Ibid., 6/44. En la misma orientación, S. Bacigalupo, La responsabilidad penal de las personas jurídicas. Barcelona 1998, pp. 153-155.

49 Críticamente, Lüderssen. "El DP entre el funcionalismo y el pensamiento vinculado a los principios "europeos tradicionales". O ¿adiós al "DP curopeo tradicional"?». En: Cuadernos de Doctrina y" Jurisprudencia Penal 9/1999, p. 65 y ss. Muñoz Conde. "Presente y futuro de la dogmática jurídico-penal». En: Revista Penal 5/2000, pp. 47-48.

50 Caro Coria. CP \& legislación complementaria. Lima 2001, p. 43 y ss. 
los órganos de ésta constituye en verdad una acción propia de la persona jurídica $^{51}$. De modo cercano, se defiende que una acción efectuada en nombre de la persona jurídica debe considerarse como una acción propia de la misma ${ }^{52}$. Esta perspectiva es compatible con los criterios de imputación previstos en algunos textos legislativos que adoptan el societas delinquere potest, por ejemplo el art. 121-2 del CP francés de 1994 establece que "Las personas jurídicas, [...], son penalmente responsables de las infracciones cometidas [...], por sus órganos o por sus representantes $[\ldots] »$.

Contra estas tesis se ha objetado por una parte que el Derecho penal sólo sanciona las acciones propias de cada persona, y por otro que las normas que se dirigen a las personas jurídicas guardan silencio sobre quien debe desempeñar las respectivas obligaciones. A lo primero ha respondido Tiedemann indicando que los ordenamientos suelen admitir la imputación del acto de un coautor a otro, siempre que éstos hayan optado por realizarlo en común, y que en todo caso es posible imputar responsabilidad al ente colectivo teniendo en cuenta su capacidad de impedir la comisión del delito ${ }^{53}$. Antes bien, una imputación similar a la de la coautoría plantea dudas si se tiene en cuenta que la decisión común, en éste caso de la persona jurídica y sus miembros, requiere de la capacidad de voluntad del ente colectivo que es lo que precisamente se quiere demostrar.

Contra la segunda objeción ha precisado Tiedemann que la persona jurídica es la destinataria primaria de la norma penal, y que ello se deduce claramente de la fórmula del actuar por otro ${ }^{54}$ que recoge por ejemplo el $\$ 14$ del StGB, el Art. $27^{\circ}$ del CP peruano, el Art. $29^{\circ}$ pf. 3 del CP colombiano de 2000 o el Art. $31^{\circ}$ del CP español. Sin embargo, ello deja aún pendiente la fundamentación del modelo de injusto personal en el caso de los entes colectivos.

En una tercera dirección doctrinal se incardinan los planteamientos que restan valor a la construcción de un concepto de acción u omisión previo al tipo. Por ese camino se renuncia a condiciones tan sólo atribuibles a las personas naturales, siendo perfectamente factible desde

51 Heine. «La responsabilidad penal de la empresa: evolución internacional y consecuencias nacionales". En: ADP 1996, p. 29 y ss.

52 Tiedemann. Temas de DP económico y ambiental. Lima 1999, p. 218.

53 lbid., pp. 219-220.

54 Ibid., p. 221. 
una perspectiva sistemática otorgar relevancia penal a los actos de las personas jurídicas. Si "persona" es todo sujeto con capacidad jurídica plena, la persona jurídica, al igual que la física, podrá ser sujeto de imputación normativa ${ }^{55}$.

Zúñiga Rodríguez ha advertido en ese sentido que la acción penal ha dejado de ser el "punto de arranque" de la imputación penal, sobre todo porque cumple más bien una función negativa, de exclusión del injusto. Lo importante no es la acción penalmente relevante, sino la dañosidad social evitable, el resultado que viene a ser la plasmación del riesgo desaprobado por el ordenamiento (suceso evitable que lesiona o pone en peligro bienes jurídicos) $)^{56}$. De tal modo, apuesta por la construcción de un sistema de imputación propio para la persona jurídica sustentado exclusivamente en las categorías de injusto y culpabilidad ${ }^{57}$.

La autora antes citada precisa que si se entiende la concepción del hecho penalmente relevante como el comportamiento de sujetos destinatarios de la norma penal, a los que les llega el mandato de valoración y el mandato de determinación, o sea que son motivables por dicha norma, no existe inconveniente en sostener que las personas jurídicas pueden ser sujetos activos ${ }^{58}$. Sobre esa base, Zúñiga Rodríguez construye un sistema de imputación propio de la persona jurídica, fundando el injusto conforme a la actuación de sus órganos y representantes, así como por la actuación de sus componentes, precisando que «no se trata de establecer que actuación vincula a la empresa sino de ¿qué tipo de resultados son imputables penalmente a la empresa?», «no se trata de una conducta personal, sino de un resultado antijurídico evitable e imputable a la empresa" 59 .

En resumen, en el estado actual parece posible sostener la capacidad de las personas jurídicas de realizar un comportamiento penalmente relevante, aún si este juicio se vincula al examen de la tipicidad. Pese a que un sector plantea que dicha capacidad sólo debe reconocerse en el ámbito del Derecho privado, cabría responder por el contrario, como precisa

55 Serrano-Piedecasas. "Sobre la responsabilidad penal de las personas jurídicas", op. cit., pp. 131-132.

56 Zúñiga. Bases para un modelo de imputación de responsabilidad penal a las personas jurídicas, op. cit., p. 228.

57 Ibid., pp. 231 ss.

58 lbid., p. 231.

59 Ibid., pp. 231, 233, 234. 
Serrano-Piedecasas ${ }^{60}$, que: 1) tal afirmación reviste validez únicamente si se parte de un concepto de acción basado en atributos exclusivos y excluyentes de la persona humana; 2) la atribución de capacidad de acción no sólo se acepta en el Derecho privado sino también en el Derecho punitivo, concretamente en el Derecho administrativo sancionador, como se aprecia en el ámbito de la Unión Europea ${ }^{61}$ y en la mayoría de estados iberoamericanos; y 3) las personas jurídicas son destinatarias de deberes legales, de modo que no sólo tienen capacidad de cumplirlos sino también de transgredirlos ${ }^{62}$.

\subsection{Sobre el juicio de culpabilidad de los entes colectivos}

Las concepciones sicológica y normativa de culpabilidad tampoco han podido dispensar un argumento sólido para la responsabilidad penal de los entes colectivos. La primera precisa de una capacidad sicológica en el autor que motive -causalmente- el hecho doloso o imprudente, mientras que la segunda se erige sobre una categoría insegura para la imputación subjetiva, el dogma del "libre albedrío", a todas luces inverificable en el caso de las personas jurídicas, sino ya en las propias personas físicas. Tampoco la concepción de la culpabilidad, asentada en la necesidad de pena, ofrece una explicación satisfactoria para atribuir responsabilidad a dichas personas en términos de motivación normativa ${ }^{63}$.

Los esfuerzos por superar este escollo de la teoría del delito han conducido igualmente a diversas respuestas que interesa poner de relieve. Un primer sector minoritario, dentro del cual se encuentra Schünemann, ha planteado la renuncia al principio de culpabilidad en la atribución de responsabilidad penal a las personas morales, sobre la base de un «estado de necesidad de bienes jurídicos», o sea un «estado de necesidad de pre-

60 Serrano-Piedecasas. "Sobre la responsabilidad penal de las personas jurídicas", op. cit, p. 132.

61 Nieto Martín. Fraudes comunitarios (DP económico europeo). Barcelona 1996, pp. 172-173.

62 En expresiones de von Liszt. Tratado de DP. T. 2. 20 ed. Madrid 1916, pp. $287-$ 288, "cualquier sociedad puede contratar; puede también celebrar contratos dolosos o leoninos, o no cumplir los contratos celebrados, de los que se derivan obligaciones de dar».

63 Meini Méndez. La responsabilidad penal de las personas jurídicas. Lima 1999, p. 119 . 
vención en el marco de una empresa que no puede demostrar la autoría de una determinada persona natural y de que un fallo de organización de la empresa ha facilitado", lo que a su juicio no atenta contra un Derecho penal respetuoso del Estado de Derecho ${ }^{64}$.

Pero si bien este planteamiento tiene el mérito de evitar el «fraude de etiquetas» que implicaría la aceptación un concepto ficto de culpabilidad, se enfrenta al problema de reducir la imputación penal a la atribución del injusto o del hecho de la persona jurídica, dejando al margen cualquier pretensión limitadora de la responsabilidad derivada de la configuración subjetiva del ente colectivo, como se observa en el Derecho civil $^{65}$. Quizás por ello es que en los sistemas iberoamericanos la culpabilidad se aprecia como un principio irrenunciable de lege lata, como se deriva del Art. VII del CP peruano o del Art. $9^{\circ}$ del CP colombiano de 2000 , cuando no de los presupuestos constitucionales de la responsabilidad penal como se aprecia en los sistemas europeos ${ }^{66}$. A su vez, en el ámbito de los trabajos relativos al CP Tipo para Iberoamérica, se ha aceptado unánimemente la consagración del principio de culpabilidad ${ }^{67}$.

En una segunda línea se incardinan las diversas propuestas de recurrir a un concepto de culpabilidad propio de la persona jurídica. Así, en cuanto a los entes colectivos, el Tribunal Constitucional Federal alemán ha admitido, desde una perspectiva constitucional, la opción de imputar la culpa de una persona física a una persona jurídica ${ }^{68}$, mientras que el Tribunal de Justicia de la Unión Europea propone admitir una culpa propia de la empresa, determinada según criterios y estándares conocidos en el Derecho civil y administrativo. En los sistemas que admiten el societas delinquere potest, se entiende que las infracciones a favor de la agrupación se originan en la «falta de organización y que esta deficiencia determina la responsabilidad penal», lo que permite contar con un concepto de culpabilidad colectiva.

64 Schünemann. "La punibilidad de las personas jurídicas desde la perspectiva europea". En: Hacia un DP económico europeo. Madrid 1995, pp. 588-589.

65 Serrano-Piedecasas. "Sobre la responsabilidad penal de las personas jurídicas", op. cit, p. 133.

66 Hirsch. "La cuestión de la responsabilidad penal de las asociaciones de personas". En: ADPCP 1993, p. 1108.

67 Jaén Vallejo. «Principio de culpabilidad». En: Cancino. CP Tipo para Iberoamérica. Vol. I. Bogotá 2000, pp. 22-23.

68 BverfGE, vol. 20, p. 323 ss. 
Teniendo en cuenta estas experiencias, y sobre todo el sentido del $\$$ 30 de la Ordnungswidrigkeiten alemana ( $\mathrm{OWiG}$ ) o Ley de las Contravenciones $^{69}$, Tiedemann señala la posibilidad de imputar la culpa individual de los dirigentes a la empresa en los casos de "defecto de organización", es decir "cuando la agrupación como tal no responde a criterios suficientes para impedir la comisión de delitos", perspectiva que ha tenido acogida en la doctrina alemana y español ${ }^{70}$. A las personas jurídicas, al ser destinatarias de las normas de conducta, puede exigírseles que se organicen contando con medidas de vigilancia y control oportunas, para evitar la comisión de delitos por parte de sus miembros ${ }^{71}$.

Como precisa Zúñiga Rodríguez, si la imputación se fundamenta en la funcionalidad social de la conducta, la potencialidad de la persona jurídica de crear riesgos para los bienes jurídicos, puede expresarse en el hecho de poseer una actitud criminal de grupo o una política o "clima" que favorece la comisión de delitos, presentándose pues un defecto de organización, de ahí que la infracción del deber de vigilancia, la «culpa in vigilando" o "in eligendo", puede ser expresión del defecto de organización o la política favorecedora de la realización del delito de la empre$\mathrm{sa}^{72}$. En esa medida, el defecto de organización se presenta como el fundamento de la culpabilidad de la persona jurídica, de modo similar a como sucede por ejemplo en los casos de actio liberae in causa $^{73}$, no se sanciona por el hecho individual, sino por la falta de cuidado en un momento anterior que hubiese permitido evitar el hecho delictivo ${ }^{74}$.

Una orientación semejante se observa en un sector de la doctrina italiana que recurre a la noción de riesgo de la actividad de las empresas a fin de sustentar su responsabilidad penal o justificar la imputación de los delitos de sus representantes a éstas, por su parte la Ley federal suiza sobre el impuesto federal directo de 1990 , así como el citado $\$ 30$ de la citada OWiG plantean la imputación cuando la actividad delictuosa genera una ventaja económica para la empresa ${ }^{75}$.

69 Malamud. Persona jurídica y penalidad, op. cit, pp. 1 ss.

70 Tiedemann. Temas de DP económico y ambiental, op. cit, pp. 222, 223, 224.

71 Tiedeman. "Die "Bebussting" von Unternehmen nach dem 2. Gesetz zur Bekämpfung der. Wirtschaftskriminalität”. En: NJW41/1988, p. 1172.

72 Zúniga. Bases para un modelo de imputación de responsabilidad penal a las personas jurídicas, op. cit, p. 239.

73 Martínez-Buján Pérez. DP económico. PG. Valencia 1998, p. 239.

74 Bacigalupo, La responsabilidad penal de las personas juridicas, p. 172.

75 Tiedemann. Temas de DP económico y ambiental, op. cit., pp. 223-224. 
Ahora bien, la noción de «culpabilidad por defecto de organización» no está exenta de críticas, principalmente porque se distanciaría del presupuesto básico de la culpabilidad cual es la atribución personal, en estos casos se estaría admitiendo una culpabilidad por el hecho ajeno ${ }^{76}$. En todo caso, dicha culpabilidad debería tener como presupuesto imprescindible la realización de un hecho típico, de lo contrario se estaría aceptando la vigencia de una culpabilidad sin antijuricidad, más aún cuando la organización defectuosa no puede ser llevada a cabo por la propia persona colectiva sino por sus órganos ${ }^{77}$, lo que conduciría a admitir un "modelo de analogía en la culpabilidad» o culpabilidad ficti$\mathrm{Cia}^{78}$.

Un tercer camino, planteado por Hirsch, señala la atribución de una culpabilidad propia a las entidades colectivas, tomando en cuenta que poseen voluntad propia para disponer libremente de sí mismas y que es un hecho socialmente aceptado imputar culpa a una empresa por su actividad ilícita. Tal construcción no se identifica con una "culpabilidad colectivan, la persona jurídica no equivale a la suma-de persona individuales, es una creación particular que se diferencia de sus propios miembros, de allí que la culpabilidad de la corporación es distinta de la culpabilidad de sus integrantes, debiendo decidirse sobre ambas por separado ${ }^{79}$.

Para Hirsch, se requiere una acción ejecutada por un órgano o representante, acción que debe mantener una "relación funcional" con la actividad de la empresa y no debe tratarse de cualquier acción posible dentro de la empresa. Por ello, la culpabilidad de la persona jurídica se determina a partir de la culpabilidad del órgano que ejecutó la acción, se trata de la acción del órgano como hecho de conexión. Además de la constatación de dicha culpabilidad, es preciso que el hecho delictivo pudiese ser evitado por la persona jurídica. Como consecuencia final, la persona jurídica tiene una "responsabilidad colectiva" por el hecho, al margen de la responsabilidad del órgano que actuó y sin que ello viole el ne bis in idem ${ }^{80}$.

76 Martínez-Buján. DP económico. PG, cit., p. 238.

77 Ibid., p. 240.

78 Roxin. DP. PG. T I. Madrid 1997, \$8/56c.

79 Hirsch. «La cuestión de la responsabilidad penal de las asociaciones de personas", cit., p. 1101.

80 Ibid., pp. 1108 ss. 
Contra esta construcción, se ha señalado que reposa en una teoría del delito basada exclusivamente en la responsabilidad individual, no se aborda el problema central de la responsabilidad penal de la persona jurídica, se obvia «llevando el problema al terreno de una responsabilidad solidaria de la persona jurídica con el órgano", solidaridad que tampoco conoce el Derecho penal de la responsabilidad individual, ni fundamenta el citado autor ${ }^{81}$. Por lo demás, este «modelo simple de imputación", como lo denomina Roxin, tropieza con la objeción de que la imputación de una acción ajena no es una acción propia de la persona colectiva y la imputación de la culpabilidad ajena tampoco es culpabilidad propia de la persona colectiva ${ }^{82}$.

\subsection{Consecuencias jurídicas aplicables a las agrupaciones}

A fin de contrarrestar la responsabilidad penal de los entes colectivos se ha puesto de relieve el "principio de personalidad de las penas" que, junto a la exigencia de culpabilidad individual, impediría que el castigo $y$, como también se ha sostenido, «sus efectos", recaigan sobre las personas que lo componen ${ }^{83}$.

En la línea contraria, se ha defendido que las penas para las personas jurídicas no tienen que ser las mismas que las establecidas para las personas físicas, sino otras equivalentes. Asimismo, las personas jurídicas sí responderían, si se les reconoce capacidad de acción y de culpabilidad, como se evaluó anteriormente. A su vez, las penas podrían cumplir las funciones de retribución y prevención a través de las personas individuales que conforman la persona jurídica y actúan por ella ${ }^{84}$.

En el marco de este debate, además de la opción de derivar la sanción de las personas jurídicas al Derecho administrativo sancionador, se ha planteado una serie de alternativas en cuanto a las consecuencias jurídicas aplicables a dichas personas dentro del sistema penal, concretamente el recurso a medidas de seguridad, la instrumentación de "consecuencias accesorias" como las previstas en el Derecho peruano y español, así

81 Bacigalupo, op. cit, pp. 176-177.

82 Roxin. op. cit, $\$ 8 / 56 \mathrm{c}$.

83 Serrano-Piedecasas. op. cit, p. 134.

84 Abanto Vásquez. DP económico. Consideraciones juridicas y económicas. Lima 1997, p. 157. 
como la imposición de penas propiamente dichas como en los sistemas anglosajones.

El recurso al Derecho administrativo para sancionar a las personas jurídicas viene suscitando dos problemas principalmente. Por un lado no existe unanimidad en torno a la justificación de la sanción administrativa para la persona moral, teniendo en cuenta la actual tendencia a dotar a la punición administrativa de las mismas garantías que el Derecho penal, por entenderse que ambos sectores expresan un mismo ius puniendi estatal ${ }^{35}$. En tal sentido, sino es de aceptarse la capacidad de acción y de culpabilidad de los entes colectivos en el Derecho penal, tampoco podría aceptarse dentro del Derecho contravencional ${ }^{86}$.

Esta solución se enfrenta al hecho que de lege lata la mayoría de sistemas jurídicos, aún los que desconocen la irresponsabilidad penal de los entes colectivos, se decantan a favor de la instrumentación de sanciones administrativas contra éstos, sobre todo en la regulación del orden socioeconómico. Y esta realidad legislativa tiene fundamentos si se acepta que la atribución de responsabilidad administrativa, sin desconocer su vinculación a los principios básicos del orden penal como los de legalidad o culpabilidad, puede operar en función de reglas menos rígidas que las del Derecho penal o conceptos amoldables a las necesidades de la injerencia administrativa ${ }^{87}$.

De allí que se acepte por ejemplo la desvinculación del ilícito administrativo del principio de lesividad o se admita, sin más, la sanción de infracciones formales o de mera desobediencia. Por esa línea de flexibilización de las reglas de imputación administrativa, pueden tener cabida las distintas construcciones que otorgan capacidad de acción y de culpabilidad a la persona jurídica, como lo reconoce por ejemplo la STC español 246/1991 de 19 de diciembre o la STS español de 3 de julio de 1992 (ponente Bacigalupo Zapater).

85 Quintero Olivares. "La autotutela. Los límites al poder sancionador de la administración pública y los principios inspiradores del DP». En: RAP 126/1991, p. 253 y ss. Danós Ordónez. «Notas sobre la potestad sancionadora de la administración pública». En: Ius et Veritas 10/1995, pp. 149ss.

86 Gracia Martín. «La cuestión de la responsabilidad penal de las propias personas jurídicas". En: AP 1993, pp. 589ss. Meini. La responsabilidad penal de las personas jurídicas, op. cit, p. 141.

87 Cid Moline. "Garantías y sanciones (argumentos contra la tesis de la identidad de garantías entre las sanciones punitivas)». En: RAP 140/1996, p. 131 y ss. Peña Cabrera. Tratado de DP. PE. T III. Lima 1994, pp. 167-168. 
El segundo problema que plantea la punición meramente administrativa de los entes colectivos se cifra en las limitaciones preventivas frente a hechos que merecen una intensa desvaloración por lesionar gravemente los bienes más importantes del sistema jurídico ${ }^{88}$, como la vida o la salud de las personas, el ambiente natural, etc. En estos casos, las comunes dificultades para la determinación de la responsabilidad penal individual junto a la imposibilidad de sancionar a la persona jurídica, peor aún cuando no se quiere aceptar la de índole administrativa, podrían redundar en un déficit de prevención general y especial, en un sentimiento social de impunidad que nutre un «sistema de irresponsabilidad organizada».

Asimismo, aunque la sanción administrativa puede revestir igual o mayor gravedad que las de carácter penal ${ }^{89}$, no puede desconocerse el efecto estigmatizador de estas últimas pues atacan directamente el "prestigio comercial» de una empresa o de sus productos, lográndose quizás un mayor efecto preventivo general y especial.

También se ha propuesto recurrir a la "segunda vía» del Derecho penal, es decir a un modelo de medidas de seguridad que sirva «como base legitimadora de sanciones complejas, que unan elementos represivos y preventivos, para las personas jurídicas ${ }^{00}$. La fundamentación de tal intervención se ha sostenido desde dos direcciones, una apunta a la peligrosidad de las personas que integran el ente colectivo, la otra se erige sobre la noción de peligrosidad de la propia persona jurídica ${ }^{91}$.

La peligrosidad individual se basa en que las personas físicas que forman parte de la persona jurídica, la utilizarán como cobertura para llevar adelante acciones criminales. Esta es la línea que siguió el Art. $132^{\circ}$ del Proyecto español de Código Penal de 1980, según el cual "podrán

88 Abanto. DP económico, op. cit, p. 157.

89 Como ocurre en Perú, por ejemplo en la punición del delito de publicidad engañosa (Art. $238^{\circ} \mathrm{del} \mathrm{CP}$ ) que prevé pena de 90 a 180 días-multa, mientras que el Art. $16^{\circ}$ del Decreto Legislativo No 691 de regulación de la publicidad, permite que la autoridad administrativa (el Instituto Nacional de Defensa de la Competencia y Protección de la Propiedad Intelectual) imponga una multa mucho mayor, de hasta 100 Unidades Impositivas Tributarias, la misma que en casos de incumplimiento de lo ordenado por la administración (Art. $2^{\circ}$ ) puede duplicarse sucesiva e ilimitadamente.

90 Roxin. op. cit, $\$ 8 / 56 b$.

91 Serrano-Piedecasas. «Sobre la responsabilidad penal de las personas jurídicas", op. cit, p. 135. 
ser sometidas a las medidas de seguridad especialmente previstas para ellas, las asociaciones, empresas o sociedades, a causa de los delitos que sus directivos, mandatarios o miembros cometieren en el ejercicio de las actividades sociales aprovechando la organización de tales entes». Los Arts. $135^{\circ}$ y $153^{\circ}$ del Proyecto previeron la posibilidad de asegurar a la persona colectiva incluso a través de medidas graves como la disolución o clausura de locales o establecimientos.

Se ha precisado, no obstante, que si en el estado actual del Derecho penal sólo son de recibo las medidas post delictuales, como signo inequívoco de una peligrosidad objetiva y no presunta, entonces el objeto de dicho juicio ha de ser la peligrosidad criminal del sujeto, lo que presenta serias dudas en el caso de las personas jurídicas, salvo que se acepte cuando menos su capacidad de acción y de realizar el injusto penal, o se traslade al ente colectivo la peligrosidad de sus órganos en tanto personas naturales con capacidad de actuación típica ${ }^{92}$, pero ello implicaría asumir un modelo de responsabilidad por el hecho ajeno.

El sustento de las medidas de seguridad también se ha derivado de la peligrosidad de la propia persona jurídica, por la potenciación del peligro que supone la actividad económica delictiva instalada en un sistema de actuación colectiva ${ }^{93}$. Más seguro que cualquier control estatal es un efectivo control interno de la empresa y sus órganos directivos, pero si no se realiza o es deficiente, "si la persona física omite o ejecuta una acción merecedora de sanción con el exclusivo objeto de beneficiar a la empresa, se justifica la imposición de una medida de seguridad ${ }^{94}$. Antes bien, para un sector doctrinal, aunque podrá hablarse de peligrosidad "sintomática", "objetiva» o "instrumental" de la persona jurídica, en el sentido de que es utilizada para cometer delitos, dicha peligrosidad no puede calificarse de criminal ${ }^{15}$.

Frente a estas alternativas, el legislador español (Art. $129^{\circ}$ del CP) y el peruano (Art. $105^{\circ} \mathrm{del} \mathrm{CP}$ ) han adoptado el modelo de las "consecuencias accesorias» que, en el plano formal, no pueden calificarse como penas ni medidas de seguridad al contar con una regulación autónoma.

92 Bacigalupo, La responsabilidad penal de las personas jurídicas, op. cit, p. 264.

93 Schünemann. Unternebmenskriminalität und Strafrecht. Köln/Berlin/Bonn/ München 1979, pp. 254, 268ss.

94 Serrano-Picdecasas. "Sobre la responsabilidad penal de las personas jurídicas", op. cit, p. 135.

95 Martínez-Buján. DP económico. PG, op. cit, pp. 231-232. 
Antes bien, la doctrina ha dispensado un tratamiento heterogéneo a dichas consecuencias ${ }^{96}$.

Para un sector que puede estimarse mayoritario, tales medidas no ostentan naturaleza propiamente administrativa ${ }^{97}$ en atención a los fines preventivos y al órgano judicial que las impone, siendo en rigor "consecuencias accesorias de la pena", en tanto pueden ser impuestas sólo si se acredita la comisión de un delito por parte de una persona física a quien se le impone una pena, se trata pues de consecuencias accesorias de una pena previamente impuesta a un sujeto responsable criminalmente $^{98}$. Es una responsabilidad subsidiaria de la responsabilidad de una persona física que haya sido condenada previamente ${ }^{99}$, similar a la del comiso por la inequívoca finalidad preventiva inocuizadora que persigue $^{100}$.

Para otro sector minoritario, enarbolado por Gracia Martín, las consecuencias accesorias deben considerarse más bien como «consecuencias accesorias del delito", siendo suficiente para su imposición la presencia de actividad delictiva, sin exigirse una efectiva condena penal. Ello porque la persona jurídica puede ser peligrosa y la prevención requiere de medidas en su contra que se fundamentan en la noción de "peligrosidad objetiva o de la cosa», en este caso del ente colectivo, expresada a través de las acciones antijurídicas (injusto penal) de las personas físicas que actúan a favor o por cuenta de la persona jurídica. Si ésta se presta a ser utilizada para la realización de actividades delictivas, allí radica la peligrosidad objetiva de la agrupación ${ }^{101}$. También es minoritaria la parcela

96 Zúñiga. Bases para un modelo de imputación de responsabilidad penal a las personas jurídicas, op. cit., p. 209.

97 Castillo Alva. Las consecuencias jurídico-económicas del delito. Lima 2001, p. 274, plantea que las consecuencias accesorias previstas en el Art. $105^{\circ} \mathrm{del}$ CP peruano "tienen una naturaleza propia de las sanciones administrativas", con lo que no puede coincidirse si se entiende que no existe una distinción ontológica, cifrada en la "naturaleza de las cosas", entre una sanción administrativa y una consecuencia jurídico-penal, sino en una valoración o "desvaloración" de carácter normativa.

98 Martínez-Buján. DP económico. PG, op. cit., pp. 232. Silva. "Responsabilidad penal de las empresas y de sus órganos en el Derecho español", op. cit, p. 363.

99 Bacigalupo, La responsabilidad penal de las personas jurídicas, op. cit, p. 282.

100 Martínez-Buján. DP económico. PG, op. cit, pp. 232.

101 Gracia Martín y otros. Las consecuencias juridicas del delito en el nuevo CP español. Valencia 1996, p. 457. 
doctrinal que concede carácter de pena a las "consecuencias accesorias»" destacando la construcción de Zugaldía, para quien el único modo de dar cumplimiento a las garantías constitucionales es considerar que estamos ante penas en sentido estricto ${ }^{103}$.

En todo caso, frente a la instauración de las consecuencias accesorias en el ordenamiento español se ha precisado que a diferencia de las clásicas medidas de seguridad o del comiso, éstas podrían repercutir sobre determinados grupos de personas, como los trabajadores o los socios de la empresa, lo que infringiría el principio de personalidad de las penas y proporcionalidad, razón por la cual no cabe sino una aplicación cautelosa de tales medidas ${ }^{104}$.

Sin embargo, una limitación importante de esta forma de «responsabilidad accesoria" se cifra en que el carácter accesorio de las medidas implica, al menos para la doctrina mayoritaria, la necesidad de una previa declaración de responsabilidad penal de una persona física, de forma que serán inaplicables allí donde precisamente se requiere una intervención preventiva frente a la criminalidad empresarial, en los supuestos en que no se puede atribuir el hecho delictivo cometido a través de una empresa a una persona física determinada ${ }^{105}$.

La opción de imponer penas a las personas jurídicas se ha fundamentado tanto desde la retribución, como a partir de la prevención general y especial. Para Tiedemann, si se admite la posibilidad de una culpabilidad moral social de la agrupación, entonces corresponde otorgarle valor a la idea de retribución. Con relación a la prevención general, sostiene que la condena penal de la empresa evidencia que la nurma jurídica vulnerada se dirige a ella y que tal violación merece una reprobación

102 Muñoz Conde. "Cuestiones dogmáticas básicas en los delitos económicos", op. cit, p. 71 . Arroyo Zapatero. "DP económico y Constitución”. En: Revista Penal 1/ 1997, p. 14.

103 Zugaldía. "Las penas previstas en el Art. $129^{\circ} \mathrm{del}$ CP para las personas jurídicas. Consideraciones teóricas y consecuencias prácticas". En: PJ 46/1997, pp. 284 285. En el mismo sentido, Bacigalupo, La responsabilidad penal de las personas jurídicas, op. cit, p. 286.

104 Serrano-Piedecasas. «Sobre la responsabilidad penal de las personas jurídicas», op. cit, p. 136. Silva. «Responsabilidad penal de las empresas y de sus órganos en el Derecho español", op. cit, p. 364.

105 Silva. "Responsabilidad penal de las empresas y de sus órganos en el Derecho español», op. cit, p. 363. 
social. La prevención especial para dicho autor también es realizable, la empresa condenada será intimidada para no reincidir en el delito, las reglas de derecho comercial y otras referidas a la vigilancia interior de la administración, pueden determinar que los dirigentes no continúen o no reiteren su actividad delictuosa. De esta forma, es posible erigir un sistema de responsabilidad penal de la persona jurídica paralelo al de la persona física, sin importar la forma jurídica de la agrupación, siendo posible incluir a las personas jurídicas de Derecho público ${ }^{106}$.

Contra estos planteamientos se han sostenido las limitaciones de un sistema de sanciones contra la persona jurídica. Además de los indudables problemas procesales que plantea la persecución penal del ente colectivo ${ }^{107}$, en tanto se considera que la multa es la pena más adecuada para la empresa, se cuestiona su eficacia preventiva ${ }^{108}$, a la luz por ejemplo del famoso caso de Cementos de Heidelberg S.A., donde una multa administrativa elevada no determinó siquiera la renuncia de los autores individuales del hecho. De otra parte, la pena de confiscación de los beneficios ilícitamente obtenidos tampoco aseguraría los fines de prevención, pues sólo lograría restablecer las cosas al estado anterior. A su turno, la imposición de otras penas pecuniarias o algunas que afecten el funcionamiento de la entidad social, no sería otra cosa que un castigo colectivo que afecta a sujetos ajenos al manejo de la empresa, como los socios, los trabajadores, etc. También se ha precisado que de castigarse simultáneamente al directivo responsable personal del hecho delictivo, se estaría convalidando una violación del ne bis in idem ${ }^{109}$.

Estas dudas han sido valoradas por Zúñiga Rodríguez, quien ha sugerido un sistema de penas aplicables a las personas jurídicas, pero acorde con un Derecho penal de mínima intervención, lo que a su juicio implica en primer término delimitar el ámbito de supuestos típicos

106 Tiedemann. Temas de DP económico y ambiental, op. cit, pp. 226-228.

107 Ibid., pp. 228-229. Abanto. DP económico, op. cit., p. 157. SAN MARTÍN CASTRO. "Delito socioeconómico y proceso penal: El Derecho procesal penal económico". En: Advocatus 4/2001, p. 294.

108 Terradillos Basoco. DP de la empresa. Madrid 1995, p. 62, sobre todo en los casos de empresas que ocupan un lugar privilegiado en el mercado, de modo que la multa puede operar como un simple costo empresarial a ser amortizado a través del precio, como cargo a los consumidores.

109 Serrano-Piedecasas. "Sobre la responsabilidad penal de las personas jurídicas", op. cit, pp. $134-135$. 
mediante numerus clausus de delitos que prevén la sanción de la persona jurídica, concretamente los denominados delitos socioeconómicos en sentido amplio ${ }^{110}$. En cuanto a las características de tales sanciones, ha propuesto principalmente: 1) Que no puedan ser absorbidas por los costes de la empresa a fin de conservar el efecto intimidatorio; 2) que ataquen los beneficios económicos mediante el comiso de ganancias, la eliminación de las subvenciones, eliminación de derechos, etc.; 3) que cualquier intervención judicial de la empresa concilie los intereses en juego de los socios, accionistas, trabajadores, etc., para lo cual se ha planteado en el sistema alemán la sanción de curatela; 4) la utilización de la reparación civil como "tercera vía», de forma que se sancione a la empresa con la restitución de la situación previa al daño; 5) renunciar a la sanción de disolución pues por su gravedad, semejante a la pena de muerte, debería restringirse para las asociaciones ilícitas; $y, 6$ ) reconocer que las sanciones contra los directivos son paralelas a las de la persona jurídica ${ }^{111}$.

La revisión efectuada permite concluir que en el estado actual del Derecho penal es posible, aunque no sin críticas, sustentar la capacidad de acción, de culpabilidad y de punición de las personas jurídicas. Sin embargo, y especialmente en lo que respecta a los sistemas jurídicos iberoamericanos, tributarios por años del societas delinquere non potest, aún hace falta ampliar la investigación penal en orden a establecer las condiciones materiales de imputación penal y procesal de la persona moral.

Como ha precisado Bustos Ramírez, todavía no hemos llegado a esta etapa de construcción del sistema penal, lo que hace preciso buscar fórmulas, como la del "actuar por otro" y las consecuencias accesorias, que nos permitan en el plano político criminal establecer bases dentro de la dogmática actual para establecer la responsabilidad penal de la persona jurídica $^{112}$. En esa perspectiva se incardina el CP peruano de 1991.

110 Zúñiga. Bases para un modelo de imputación de responsabilidad penal a las personas jurídicas, op. cit, p. 242, n. 127.

111 Ibid., p. 240.

112 Bustos Ramírez. «La responsabilidad penal de las personas jurídicas». Inédito. Lima 2000 , p. 3. 


\section{IV.¿̨Necesidad de adoptar el societas delinquere potest en el derecho penal peruano?}

En el ordenamiento penal peruano, la jurisprudencia ha defendido unánimemente el principio societas delinquere non potest ${ }^{13}$. Por su parte, la doctrina tradicionalmente se ha mostrado contraria a aceptar la responsabilidad penal de las personas jurídicas ${ }^{114}$, pero en los últimos años,

113 La Corte Suprema declaró la insubsistencia de todo lo actuado e improcedente la acción del agraviado contra la Fabrica de Velas y Jabones "La Excelsior", imputándole la comisión del delito de falsificación (Art. $377^{\circ}$ del CP de 1924) por usar indebidamente la marca "Jabón Patito", que él había registrado como distintivo de los jabones que producía (Anales Judiciales, 1934, p. 137). El enjuiciamiento supone la imputación de hechos delictuosos a personas individuales determinadas sobre quienes puede recaer la sanción respectiva (Anales Judiciales, 1918, p. 47). En un juicio por calumnia imputada a una sociedad comercial, se determinó que la responsabilidad penal es esencialmente individual (Ejecutoria Suprema de 8-4-1920, en: Anales Judiciales, 1920, p. 16). En un proceso por apropiación ilícita se estableció que las personas jurídicas no pueden ser sujetos activos de algún delito, ya que dicha calidad sólo puede ostentarla la persona física, pues sólo ella es capaz de ejercitar acciones o incurrir en omisiones que caigan en el ámbito del DP (Ejecutoria Suprema de 3-1-1972, en : Revista de Jurisprudencia Peruana 338, p. 357). "El encausado resulta ser una persona jurídica como Sociedad Comercial de Responsabilidad Limitada (SCRLtd.), por lo que no se le debió instaurar proceso penal, debiendo identificarse en todo caso a la persona que actuó como órgano de representación o como socio representante autorizado de ella, en vista que la persona jurídica como tal, de acuerdo al principio societas delinquere non potest, no posee capacidad de conducta, recayendo en todo caso dicho atributo sólo en las personas naturales, tal como lo prescribe el artículo $27^{\circ}$ del CP" (Resolución de la Corte Suprema de 24-10-97, Consulta 3963-96, en: Gaceta Jurídica. Guía Rápida de Jurisprudencia penal y procesal penal. Lima 2001, p. 45). En nuestro ordenamiento penal no se admite la responsabilidad de las personas jurídicas; la responsabilidad penal se extiende a las personas que actúan en nombre de las personas jurídicas. Resulta inaceptable tener como denunciado a una persona jurídica (Resolución de la Corte Superior de Lima de 19-12-97, exp. 3045-97, en: La Rosa Gómez de la Torre. Jurisprudencia del proceso penal sumario. Lima 1997. p. 79).

114 Antes de la vigencia del CP de 1991, Vid., Montoya Manfrcdi. Responsabilidad de los directores de las sociedades anónimas. 2a ed. Lima 1977, p. 24. García Rada. Sociedad anónima y delito. $2^{\text {a }}$ ed. Lima 1985, p. 65. Hurtado Pozo. Manual de DP. PG. 2a ed. Lima 1987, pp. 340-341. Peña Cabrera. Tratado de DP. PG. Vol. I. $3^{a}$ ed. Lima 1987, p. 161. Jara F. "¿Son las personas jurídicas sujetos de sanción penal?". En: Thémis 8/1987, p. 32. Villavicencio Terreros. Lecciones de DP. PG. Lima 1990, p. 115. Ugaz Sánchez-Moreno. "Quiebra fraudulenta». En: Revista Peruana de Derecho de la Empresa 29/1987, p. 93. Lecca Forero. La responsabilidad penal de los directores 
frente a la relevancia que ha venido cobrando la criminalidad económica se empieza a postular la revisión del societas delinquere non potest $t^{15}$, cuando no la asunción de un sistema de responsabilidad penal de los entes colectivos ${ }^{116}$.

A este contexto se ha sumado el reciente debate vinculado al llamado "Caso Montesinos», a propósito de la participación de múltiples empresarios de televisión que pactaban con el ex asesor presidencial la línea informativa y de expresión de sus medios a favor del Gobierno de Fujimori, el destino de sus causas judiciales, entre otras pretensiones ilegales, y a cambio de elevadas sumas de dinero. Hechos de esta naturaleza han originado diversas posturas en torno a la posibilidad de aplicar las llamadas consecuencias accesorias previstas en el Art. $105^{\circ}$ del CP en orden a "sancionar" no sólo a las personas físicas que pudieron cometer cohecho, tráfico de influencias o peculado, sino además al propio medio de comunicación a través del cual por ejemplo se promovió ilícitamente la reelección de Fujimori para el período 2000-2005, omitiendo cubrir las actividades proselitistas de los otros candidatos, negándose a emitir su publicidad -a pesar de ofrecerse el pago respectivo por el servicio-, difamándolos de diversos modos, manipulando las encuestas de opinión o encubriendo las graves denuncias contra el Gobierno de Fujimori por corrupción y graves violaciones de Derechos Humanos.

en las sociedades anónimas. Tesis de Bachiller. Lima 1990, p. 115 y ss. Moscoso Callo. El acaparamiento, especulación y adulteración como delitos contra la economía en el D. Leg. No 123. Tesis de bachiller. Lima 1988, p. 171. Tras la puesta en vigor del CP de 1991, Vid. Caro Coria. "La irresponsabilidad penal de la persona jurídica", op. cit, p. 78. Villa Stein. DP. PG. Lima 1998, p. 197. Peña Cabrera. PE III, cit., pp. 156ss. Tratado de DP. Estudio programático de la PG. $3^{\text {a }}$ ed. Lima 1999, pp. 291-292. Angeles Gonzáles/Frisancho Aparicio. CP I. Lima 1996, p. 434-436. Castillo. "Apuntes sobre la responsabilidad penal de las empresas y las personas jurídicas", op. cit., p. A55. Meini Méndez. La responsabilidad penal de las personas jurídicas, op. cit., pp. 169-170. Bramont-Arias, L.M. PG, op. cit., pp. 124-126. Villavicencio Terreros. CP comentado. Lima 2001, pp. 155, 275.

115 Mazuclos Coello. “DP económico y de la empresa: concepto, sistema y política criminal». En: DP económico y de la empresa. Lima 1996, pp. 37ss.

116 Abanto. DP Económico, op. cit., p. 162. Zúñiga Rodríguez. "Las consecuencias penales de los hechos cometidos por entes colectivos: de la responsabilidad individual a la responsabilidad colectiva". En: II Congreso Internacional de DP. Lima 1997, pp. 357-356. Hurtado Pozo. "Personas jurídicas y responsabilidad penal». En: ADP 1996, pp. $155-158$. 
El CP peruano de 1991, acogiendo el modelo previsto en la Propuesta de Anteproyecto de CP español de 1983, establece en el Art. 105\%, incardinado en el Capítulo II ("Consecuencias accesorias») del Título VI («De la Reparación civil y consecuencias accesorias») de la Parte General, la posibilidad de que el Juez imponga una o varias medidas a la persona jurídica si el «hecho punible» se cometió en ejercicio de su actividad, o cuando su organización permitió favorecerlo o encubrirlo ${ }^{117}$. Esta solución se ha expandido a la legislación complementaria ${ }^{118}$, como se observa en el Art. $10^{\circ}$ de la Ley No 26461 de 8 de junio de 1995, Ley de delitos aduaneros, previsto en el Capítulo V ("Consecuencias accesorias») del Título I («De los delitos aduaneros») ${ }^{119}$, o en el Art. $17^{\circ} \mathrm{del}$

117 "Artículo $105^{\circ}$.- Si el hecho punible fuere cometido en ejercicio de la actividad de cualquier persona jurídica o utilizando su organización para favorecerlo o encubrirlo, el Juez podrá aplicar todas o algunas de las medidas siguientes:

1. Clausura de sus locales o establecimientos, con carácter temporal o definitivo.

La clausura temporal no excederá de cinco años.

2. Disolución de la sociedad, asociación, fundación, cooperativa o comité.

3. Suspensión de las actividades de la sociedad, asociación, fundación, cooperativa o comité por un plazo no mayor de dos años.

4. Prohibición a la sociedad, fundación, asociación, cooperativa o comité de realizar en el futuro actividades, de la clase de aquellas en cuyo ejercicio se haya cometido, favorecido o encubierto el delito.

La prohibición podrá tener carácter temporal o definitiva. La prohibición temporal no será mayor de cinco años.

Cuando alguna de estas medidas fuera aplicada, el Juez ordenará a la autoridad competente que disponga la intervención de la persona jurídica para salvaguardar los derechos de los trabajadores".

118 Hurtado. «Personas jurídicas y responsabilidad penal», op. cit., pp. 152-154.

119 "Artículo $10^{\circ}$. Si para la ejecución del hecho punible se utilizó la organización de una persona Jurídica o negocio unipersonal, con conocimiento de sus titulares, el Juez deberá aplicar, según la gravedad de los hechos conjunta o alternativamente Las medidas siguientes:

a.- Clausura temporal o definitiva de sus locales o establecimientos.

b.- Disolución de la persona jurídica.

c.- Cancelación de licencias, derechos y otras autorizaciones administrativas o municipales de que disfruten.

d.- Prohibición temporal o definitiva a la persona jurídica para realizar actividades de la naturaleza de aquellas en cuyo ejercicio se haya cometido, favorecido o encubierto el delito.

Simultáneamente, con la medida dispuesta, el Juez ordenará a la autoridad competente la intervención de la persona jurídica para los fines legales correspondientes, con el objeto de salvaguardar los derechos de los trabajadores y acreedores". 
D.Leg. No 813 de 24 de abril de 1996, Ley de delitos tributarios, ubicado en el Título IV que regula las «Consecuencias accesorias» ${ }^{120}$.

La exposición de motivos del CP no precisó los fundamentos de esta regulación ${ }^{121}$, mientras que la del D. Leg. No 813 se limitó a calificarlas como "medidas administrativas" ${ }^{122}$. Sin embargo, debe entenderse que con ello el legislador peruano ha zanjado definitivamente la cuestión de la responsabilidad penal de las personas jurídicas, cuando menos en lo formal, a favor del societas delinquere non potest, dado que las "consecuencias accesorias" no forman parte de catálogo de penas (Art. $28^{\circ} \mathrm{del}$ CP) ni de medidas de seguridad (Art. $71^{\circ}$ del CP) ${ }^{123}$. En todo caso, la interpretación de la cláusula del Art. $105^{\circ}$ del CP peruano no ha sido pacífica en la doctrina nacional, a lo que debe sumarse la no aplicación del precepto en la jurisprudencia a pesar de sus casi once años de vigencia, tanto quizás por desconocerse sus alcances o por entenderse que se trata de medidas graves (clausura de locales, disolución, etc.) de excepcional imposición.

120 «Artículo $17^{\circ}$.- Si en la ejecución del delito tributario se hubiera utilizado la organización de una persona jurídica o negocio unipersonal, con conocimiento de sus titulares, el Juez podrá aplicar, conjunta o alternativamente según la gravedad de los hechos, las siguientes medidas:

a) Cierre temporal o clausura definitiva del establecimiento, oficina o local en donde desarrolle sus actividades.

El cierre temporal no será menor de dos ni mayor de cinco años.

b) Cancelación de licencias, derechos y otras autorizaciones administrativas.

c) Disolución de la persona jurídica».

121 La Exposición de Motivos del CP señala que «Resaltan, por su importancia y novedad, las distintas medidas aplicables a las personas jurídicas cuando el delito fuera perpetrado por personas naturales que actúen en ejercicio de las actividades sociales o utilizando la organización para favorecer u ocultar las infracciones penales. Entre las medidas enumeradas en el proyecto destacamos las siguientes: clausura de la empresa, disolución de la sociedad, asociación o fundación, y suspensión o prohibición de actividades (artículo 105\%)"

122 El ítem 7 de la Exposición de Motivos del D.Leg. No 813 precisa:

"DE LAS CONSECUENCIAS ACCESORIAS.-

En la ejecución de los delitos de Defraudación Tributaria se utiliza generalmente la organización de personas jurídicas, quienes se benefician ilícitamente. En este sentido, es necesario que la ciudadanía constate, que las sentencias emitidas por el Órgano Jurisdiccional, contengan medidas administrativas contra las personas jurídicas que se benefician con la comisión del delito".

123 Villavicencio. CP comentado, op. cit., p. 275. 
Ahora bien, el principal aspecto a dilucidar en torno al Art. $105^{\circ}$ se cifra en establecer, como sucede a raíz de la interpretación del Art. $129^{\circ}$ del CP español de $1995^{124}$, si estamos ante "consecuencias accesorias de la pena" o "consecuencias accesorias del delito". En la primera dirección se ha pronunciado Meini Méndez, para quien la imposición de medidas contra la persona jurídica implica de lege lata la existencia de un hecho antijurídico, culpable y merecedor de pena ${ }^{125}$, de manera tal que no podrán aplicarse ante cualquier causal de ausencia de culpabilidad o exclusión de pena, aunque admite, a fin de evitar lagunas, su aplicación cuando la pena no llegue a ejecutarse, por ejemplo en los casos de suspensión de la ejecución de la pena, más no en los supuestos de reserva del fallo condenatorio ${ }^{126}$.

Contra estas consideraciones y en orden a sostener la segunda postura antes enunciada, Castillo Alva ha planteado la necesidad de interpretar el Art. $105^{\circ}$ con mayor amplitud, en el sentido de considerar que la exigencia de un "hecho punible» se satisface con la presencia de un acto típico y antijurídico o injusto penal, lo que refrenda un sector de la doctrina penal ${ }^{127}$ y, hasta cierto punto, la propia sistemática del Código Penal peruano ${ }^{128}$.

Desde el punto de vista sistemático, independientemente del caso aislado del delito ambiental (Art. $314^{\circ}$ del $\mathrm{CP}^{129}$ ) en que se prevé la aplicación del Art. $105^{\circ}$ como medida cautelar ${ }^{130}$, la regulación no es uniforme. Existe una marcada semejanza entre el Art. $105^{\circ}$ del CP y el citado Art. $10^{\circ}$ de la Ley de Delitos Aduaneros ( Si para la ejecución del hecho punible $[\ldots] »)$, pues en ambos casos se vincula la medida a un

124 Vid. Supra 3.3. Fernández Teruelo. «Las consecuencias accesorias del artículo $129^{\circ}$ CP». En: Quintero Olivares/Morales Prats. Elnuevo DPespañol. Pamplona 2001, p. 275.

125 Similar, Abanto. DP económico, op. cit., p. 158.

126 Meini Méndez. La responsabilidad penal de las personas jurídicas, op. cit., pp. 198-199.

127 Feijóo. «La responsabilidad penal de las personas jurídicas», op. cit., p. 286.

128 Castillo. Las consecuencias jurídico-económicas del delito, op. cit., pp. 282 284.

129 «Artículo 314.- El Juez Penal ordenará, como medida cautelar, la suspensión inmediata de la actividad contaminante, así como la clausura definitiva o temporal del establecimiento de que se trate de conformidad con el artículo $105^{\circ}$ inciso 1 , sin perjuicio de lo que pueda ordenar la autoridad en materia ambiental".

130 Caro Coria. La protección penal del ambiente. Lima 1995, pp. 355-357. 
«hecho punible». Sin embargo, el Art. $3^{\circ}$ de la Ley No 27270 contra actos de discriminación de 29 de mayo de 2000, prevé la posible aplicación de la medida de clausura temporal del Art. $105^{\circ}$ del CP en los casos del «delito tipificado en el artículo $323^{\circ}{ }^{131}$, exigencia de delito que parece apreciarse a su vez en el Art. $17^{\circ}$ de la Ley Penal Tributaria antes mencionada ( $\mathrm{Si}$ en la ejecución del delito tributario [...]»). Ni siquiera la propia expresión «hecho punible» puede interpretarse unitariamente dentro del CP, en algunos casos parece referirse con propiedad a un delito (acto típico, antijurídico, culpable y punible), mientras que en otros únicamente al injusto penal (acto típico y antijurídico) ${ }^{132}$.

Esta pluralidad de significados del "hecho punible» permite compatibilizar la interpretación del Art. $105^{\circ}$ con un mínimo de garantías para la persona jurídica y el objetivo de evitar lagunas de punibilidad en perjuicio de la prevención especial. De este modo, la delimitación del hecho punible como injusto personal resulta más satisfactoria en el contexto político criminal del Art. $105^{\circ}$. No parece del todo razonable que se haga depender la aplicación de las medidas accesorias de la culpabilidad del autor, especialmente en los casos de mayor gravedad, que son en los que conforme al principio de proporcionalidad podrá aplicarse estas medidas ${ }^{133}$, y más aún si en la vía administrativa no existe una medida equivalente susceptible de ser aplicada ${ }^{134}$.

Ahora bien, fuera del aspecto formal y de posibles sfraudes de etiquetas", no cabe duda que las "medidas accesorias» son verdaderas sanciones contra personas jurídicas pues implican una limitación coactiva de derechos ${ }^{135}$. De allí deriva la necesidad de contar con criterios claros en torno a su imputación penal y procesal ${ }^{136}$, aspectos cuyo desarrollo en

131 «Artículo $3^{\circ}$.- El Juez podrá aplicar la clausura temporal a que se refiere el Artículo $105^{\circ}$ del Código Penal, en los casos del delito tipificado en el Artículo $323^{\circ}$, por el término que sumado a la sanción administrativa no exceda de 5 (cinco) años».

132 Vid. los arts. $1^{\circ}, 6^{\circ}, 13^{\circ}, 15^{\circ}, 22^{\circ}, 23^{\circ}, 24^{\circ}, 25^{\circ}, 26^{\circ}, 39^{\circ}, 46^{\circ}, 46-\mathrm{A}$ y $51^{\circ}$ del CP, así como el rótulo del Título II de la PG.

133 Zúniga. Bases para un modelo de imputación de responsabilidad penal a las personas jurídicas, op. cit., p. 213.

134 Fernández. "Las consecuencias accesorias del Art. $129^{\circ}$ CP», op. cit., p. 276.

135 Abanto. DP económico, op. cit., p. 158. Para Hurtado. «Personas jurídicas y responsabilidad penal", op. cit., p. 151 , se trata de "sanciones impuestas a la persona jurídica de manera simulada".

136 Fernández. "Las consecuencias accesorias del Art. $129^{\circ} \mathrm{CP}$, op. cit., pp. 281282. 
nuestro medio se encuentra aún en sus inicios ${ }^{137}$ y que en definitiva están vinculados a la concepción de las "consecuencias accesorias" como penas, medidas de seguridad, consecuencias sui generis o, como aquí se defiende, medidas fundadas en la "peligrosidad objetiva de la cosa»" ${ }^{138}$.

En esa línea de pensamiento, Feijóo Sánchez ha centrado el debate en torno a los criterios de imputación de las consecuencias accesorias sobre la base de la peligrosidad de la cosa, precisando una serie de aspectos que, descontando los ya abordados, merecen prestar atención ${ }^{139}$. Por un lado debe quedar claro, en el terreno formal, que la no fundamentación de esa peligrosidad en necesidades de prevención general sino de prevención especial, hace innecesario el recurso a un estricto sistema de numerus clausus, como el acogido por el Art. 129.1 del CP español de 1995, que señale en la parte especial los casos en lo que es posible imponer la medida accesoria. De ese modo, será suficiente una cláusula general como la del Art. $105^{\circ}$ del CP peruano ya que una fundamentación preventivo especial se orienta a una solución individual, la que además es compatible con la regulación facultativa («el Juez podrá ") ${ }^{140}$ que permite evaluar su imposición judicial, según se verá luego, en una prognosis de que la agrupación puede seguir siendo utilizada delictivamente.

De otra parte, es necesario delimitar el núcleo de autores cuyos hechos pueden permitir la imputación jurídico-penal a las personas jurídicas, siendo que la tendencia en la doctrina y en el Derecho comparado se ubica entre un modelo puramente formal que exige la actuación de órganos y/o representantes legales jurídicamente cualificados para ac-

137 Vid. sobre todo, Mcini. La responsabilidad penal de las personas jurídicas, $o p$. cit., p. 200 y ss. Castillo, Las consecuencias jurídico-económicas del delito, op. cit., p. 285 y ss.

138 Bramont-Arias, L.M. PG, op. cit., p. 404. Villa Stein. PG, op. cit., p. 504.

139 En lo que sigue, Feijóo. «La responsabilidad penal de las personas jurídicas", op. cit., pp. 278-291.

140 Ese carácter facultativo se mantiene en el Art. $323^{\circ}$ del CP y en el Art. $17^{\circ}$ del D. Leg. No 813. Por el contrario, el Art. $10^{\circ}$ de Ley No 26461 torna en obligatoria la medida ( El Juez deberá aplicar»), al igual que el Art. $241^{\circ}$ pf. 2 que prevé en los delitos de fraude en remates, concursos o licitaciones públicas que «Si se tratare de concurso público de precios o de licitación pública, se impondrá además al agente o a la empresa o persona por él representada, la suspensión del derecho a contratar con el Estado por un período no menor de tres ni mayor de cinco años". 
tuar en nombre de la persona jurídica, y el modelo contrario que otorga relevancia a los actos de todo aquél que actúe en nombre de la empresa o a favor de ella. Esta última pareciera ser la opción asumida en el Art. $105^{\circ}$ del CP al referirse al hecho punible que «fuere cometido en el ejercicio de la actividad de cualquier persona jurídica o utilizando su organización para favorecerlo o encubrirlo ${ }^{141}$. Pero teniendo en cuenta la gravedad de las medidas accesorias y el principio de proporcionalidad, es posible plantear una restricción semejante a la del Model Penal Code de Estados Unidos, dejándose de lado las acciones de personas que carecen de poder de decisión ${ }^{142}$, bajo el entendido de que la gravedad de la consecuencia debe corresponder a hechos de especial relevancia cuya comisión sólo es posible en ejercicio de ese poder de decisión, lo que indudablemente permite incluir los cargos intermedios así como a los encargados o jefes de una sección o unidad operativa con enormes capacidades decisorias $^{143}$.

Tampoco es razonable que toda actuación de un representante u órgano de dirección determine consecuencias penales para el ente colectivo, por ello debe delimitarse el hecho de conexión que legitima la intervención penal. Si se advierte la necesidad de una «específica relación normativa» entre el hecho y la actividad social, como acontece en el Art. $105^{\circ}$ del CP peruano cuando se refiere al "ejercicio de la actividad" o a la utilización de «su organización", debe elaborarse una "teoría de la imputación objetiva» propia de las personas jurídicas. En tal perspectiva, si se concibe que la peligrosidad objetiva que fundamenta la consecuencia accesoria se expresa, parafraseando a Tiedemann, en un defecto de organización ${ }^{144}$ que facilita la comisión de hechos antijurídicos, entonces dicha consecuencia sólo tiene sentido en los casos en que él hecho punible de la persona natural se debe a un defecto de organización o a una gestión criminógena del ente colectivo que se mantiene o se puede repetir.

141 Meini Méndez. La responsabilidad penal de las personas jurídicas, op. cit., p. 207.

142 Malamud Goti. Política criminal de la empresa. Buenos Aires 1983, pp. 2425 , en relación a los mecanismos de división y delegación como instrumentos que favorecen la impunidad por «dificultades de detección y de localización de responsabilidades".

143 Fcijóo. "La responsabilidad penal de las personas jurídicas", op. cit., p. 281.

144 Tiedemann. Temas de DP económico y ambiental, op. cit., pp. 222, 223, 224. 
Así cobra relevancia el planteamiento de Günther Heine, en el sentido de que «una empresa dedicada a la producción de nuevos riesgos, debería de ser considerada [...] como garante de control. El deber de evitar peligros y de controlar resultan del hecho que los riesgos propios de la explotación pueden ser únicamente controlados mediante una administración de los riesgos por parte de la empresa y no mediante las disposiciones de seguridad y de control estatales» ${ }^{145}$. De esta manera, los criterios rectores para una responsabilidad -penal a juicio de Heinede la organización estarían dados por dos presupuestos: "como condición necesaria debe existir una administración deficiente del riesgo (fehlerhafte Risikomanagement); y como condición suficiente la materialización del peligro típico de la empresa» ${ }^{146}$.

Nada impide que los aportes de Tiedemann y Heine puedan llevarse al terreno de la imputación de las medidas contra las personas jurídicas del Art. $105^{\circ}$ del CP. Si se ha llegado a estimar que son suficientes para fundamentar la imposición de verdaderas penas contra una agrupación, con mayor razón (argumento «a fortiori») permitirán justificar medidas menos grave como las "consecuencias accesorias" (argumento «ad maioris ad minus"). De esta forma, debe entenderse que la medida accesoria depende de una prognosis de que la agrupación podrá seguir siendo utilizada delictivamente ${ }^{147}$, por defecto de organización o deficiente administración de riesgo. Si dicho pronóstico se desvanece debe cesar entonces la medida ${ }^{148}$. Esa prognosis no surge por el simple hecho de que la persona física actuó en beneficio o en interés de la persona jurídica, siendo en tales supuestos suficiente el recurso al comiso del Art. $104^{\circ}$ del $\mathrm{CP}^{149}$.

Tales criterios de imputación pueden asumirse en algunos casos, de lege lata, mediante la interpretación, pero no están suficientemente desarrollados en el Art. $105^{\circ}$ del CP, lo que desde ya debe motivar su revi-

145 Heine. "La responsabilidad penal de la empresa: evolución internacional y consecuencias nacionales", op. cit., p. 42.

146 Ibid., p. 42.

147 Con toda claridad, el Art. 129.3 del CP español precisa que «Las consecuencias accesorias previstas en este artículo estarán orientadas a prevenir la continuidad en la actividad delictiva y los efectos de la misman.

148 Cercano, Abanto Vásquez. DP económico. PE. Lima 2000, p. 489.

149 Feijóo. "La responsabilidad penal de las personas jurídicas", op. cit., pp. 283285. 
sión en el proceso de reforma penal iniciado en virtud de la Ley No 27421 de 7 de febrero de 2001. En ese marco deberá proponerse la ampliación de las agrupaciones a las que pueden aplicarse estas medidas, el Art. 105 se limita a las personas jurídicas en general, con o sin fines de lucro, sólo el Art. $10^{\circ}$ de la Ley No 26461 y el Art. 17 del D. Leg. No 813 prevén su aplicación a los «negocios unipersonales». Si el fundamento de las consecuencias accesorias deriva de la peligrosidad de la cosa, podrá admitirse su extensión inclusive para las agrupaciones carentes de personalidad jurídica. Antes bien, cabrá evaluar todavía la posibilidad de sancionar, como permite el CP francés de 1994 y plantea un sector de la doctrina, a las personas jurídicas de Derecho público.

En la reforma del Art. $105^{\circ}$ deberá aclararse también las reglas de individualización judicial de esta medida penal que, sobre la base de pautas preventivo especiales, no se satisface con la exigencia general de valorar la entidad del hecho punible, como ordenan el Art. $10^{\circ}$ de la Ley No 26461 y el Art. $17^{\circ}$ del D. Leg. No 813 («según la gravedad de los hechos»), sino con la incorporación de criterios como los del Art. 102.2 del Proyecto de CP Suizo de 1998, relacionados con la capacidad económica de la empresa y la necesidad de prevenir futuros delitos.

Ahora bien, la gravedad de las medidas que recoge el Art. $105^{\circ} \mathrm{del}$ CP (clausura de locales o establecimientos, disolución, suspensión de actividades y prohibición de actividades) ${ }^{150}$ puede motivar diversas valoraciones. Por un lado la presencia de consecuencias de tal entidad enerva su aplicación generalizada, debiendo recurrirse a ellas en casos excepcionales, de especial gravedad y siempre como una medida subsidiaria o secundaria ${ }^{151}$. De otra parte, de lege ferenda es necesario ampliar el catálogo de medidas a fin de prever otras menos lesivas y que pueden desplegar iguales o mayores efectos preventivo especiales, como la amonestación, la obligación de publicar la sentencia que declara la responsabilidad accesoria, el comiso de los instrumentos que sirvieron para cometer el delito y de los beneficios obtenidos, multa de acuerdo al beneficio obtenido o el daño creado por la actividad delictiva, pérdida de beneficios fiscales y subvenciones, prohibición por un periodo de participar en las contrataciones públicas, vigilancia judicial por un periodo determinado de las actividades en cuyo ejercicio se cometió el hecho punible, 
intervención judicial por un periodo a fin de cautelar los derechos de los trabajadores o de los acreedores, entre otras.

Queda también por resolver el tratamiento de las causas que extinguen la imposición y ejecución de estas medidas, como la prescripción, vacío frente al cual se ha propuesto aplicar por analogía la regulación de las medidas de seguridad ${ }^{152}$ que se fundamentan en la llamada "peligrosidad subjetiva".

Un problema particular radica en la ausencia de reglas procesales para la imposición de las consecuencias accesorias aplicables a las personas jurídicas. Para un importante sector doctrinal en estos casos la persona jurídica debe asumir la condición de parte procesal, por lo que necesariamente rige el principio acusatorio ${ }^{153}$. De esta forma, no basta una simple audiencia de los titulares como exige el Art. 129.1 del CP hispano, es necesaria la consideración del ente colectivo como parte, salvo que se ausente injustificadamente en cuyo caso se le puede declarar rebelde o contumaz, como acota San Martín Castro. Para este autor el Ministerio Público debe efectuar la imputación correspondiente y el Juez Penal dictar la resolución de imputación. De esta forma, la persona jurídica debe ser citada formalmente a cada acto procesal de trascendencia, pudiendo ofrecer pruebas y participar en sus actuaciones. También deberá ser citada con la acusación fiscal y el auto de enjuiciamiento, pudiendo intervenir en la fase intermedia y en el juicio oral, y reconociéndosele el derecho de impugnación ${ }^{154}$.

Antes bien, se ha sostenido por el contrario que no sería necesario llegar a considerar a la persona jurídica como parte en el proceso. Si la persona jurídica no es una imputada propiamente dicha, sino una cosa u objeto peligroso sobre cuyo destino debe discutirse para neutralizar esa peligrosidad ${ }^{155}$, entonces haría falta establecer todo un sistema de garantías procesales, bastando la mera audiencia con los titulares como en el ordenamiento español. Estas cuestiones deberán resolverse de lege ferenda para una eficaz y legítima imposición de consecuencias contra las personas jurídicas, sin embargo parece que no puede desestimarse,

152 Feijóo. «La responsabilidad penal de las personas jurídicas», op. cit., p. 288.

153 Bajo Fernández/Bacigalupo, DP económico. Madrid 2001, p. 155.

154 San Martín. "Delito socioeconómico y proceso penal: El Derecho procesal penal económicon, op. cit., p. 294. Similar, Castillo. Las consecuencias jurídico-económicas del delito, op. cit., pp. 306-310.

155 Feijóo. «La responsabilidad penal de las personas jurídicas», op. cit., p. 287. 
sin más, la necesidad de que la persona jurídica pasible de una consecuencia accesoria ejerza plenamente el derecho de defensa que le compete al amparo del Art. 139.14 de la Constitución.

La consideración de la agrupación como cosa u objeto peligroso no es incompatible con la conveniencia de considerarla parte en el proceso penal en el que no sólo se discutirá el destino del objeto o cosa peligrosa, sino los propios criterios de imputación de la responsabilidad accesoria, sea por defecto de organización o deficiente administración del riesgo, cuando no el destino de un ente colectivo al que pertenecen terceros interesados como los trabajadores, acreedores, socios ajenos al ilícito, entre otros. Parece pues oportuno que la determinación de estos aspectos no quede en manos sólo del Ministerio Público, del Poder Judicial, del imputado o de la parte civil, sino también de la persona jurídica que podría ser privada o limitada en el ejercicio de sus derechos a través de las consecuencias accesorias.

\section{Perspectivas de un sistema de imputación de responsabilidad en el proyecto de Código Penal tipo para Iberoamérica}

\subsection{Sobre la responsabilidad penal de las personas jurídicas}

La elaboración de la parte general del Código Penal Tipo para Latinoamérica $^{156}$, cuya redacción se concluyó en São Paulo en $1971^{157}$, no trajo consigo el debate en torno a la responsabilidad penal de las personas jurídicas ni de la actuación "en lugar de otro». El tecnicismo no ajeno a la una ideología, marcada a juicio de Zaffaroni por el idealis-

156 Grisolía. CP Tipo para Latinoamérica. PG. T. I, T. II Vols. 1-2. Santiago de Chile 1973. Bustos Ramírez/Valenzuela Bejas. DP latinoamericano comparado. T. I: PG. Buenos Aires 1981, pp. 1 y ss.

157 Como iniciativa privada se constituyó en octubre de 1963 en Santiago de Chile la Comisión Redactora de un CP Tipo para Latinoamérica, con secretariado permanente en dicha ciudad. En ese marco se celebraron reuniones posteriores en México (1965), Lima (1967), Caracas (1969), Bogotá (1969) y São Paulo (1971), ocasión en la que se ultimó la PG. Luego se efectuaron reuniones en San José (1972), Medellín (1973), Santiago (1975), San Cristobal/Venezuela (1975), Madrid (1977) y Buenos Aires (1979), Vid. Zaffaroni. "Introducción a la codificación penal latinoamericana». En: Los códigos penales iberoamericanos 1. Bogotá 1994, p. 107. 
mo neo-kantiano de Baden (Mezger) y el neoidealismo gentiliano en relación a la pena, llevó a introducir en la ley conceptos que corresponden a la doctrina e imponer la sistemática del delito dominante en los años sesenta en Latinoamérica ${ }^{158}$, de manera que se mantuvo intacto el societas delinquere non potest.

Por invitación del Gobierno de Colombia, en junio de 1994 se celebró en Cartagena de Indias la X Conferencia de Ministros de Justicia de los Países Iberoamericanos, ocasión en la que asistieron los representantes de Argentina, Bolivia, Colombia, Cuba, Chile, El Salvador, España, Guatemala, México, Panamá, Paraguay, Portugal, República Dominicana, Uruguay y Venezuela. Como observadores asistieron los representantes de Estados Unidos, el Banco Interamericano de Desarrollo y la Universidad de Puerto Rico. En esta Conferencia se adoptó, a iniciativa del Colegio de Abogados Penalistas de Santafé de Bogotá y Cundinamarca, entre otros acuerdos, la elaboración de un Código Penal Tipo Iberoamericano, nombrándose como Secretario Perpetuo de la Comisión Redactora a su Presidente, Antonio José Cancino Moreno ${ }^{159}$.

Desde la renovación de las reuniones de la Comisión Redactora del Código Penal Tipo Iberoamericano en 1995, se acordó unánimemente desarrollar los trabajos de redacción en tres ámbitos, la Ley Penal, el Hecho Punible y las Consecuencias Jurídicas del Delito. Éste último no fue objeto de tratamiento en el I Encuentro celebrado en Santafé de Bogotá/Colombia en 1995. Sin embargo, en el II Encuentro realizado en Las Palmas de Gran Canarias/España del 26 de setiembre al 2 de octubre de 1996, la representante de Costa Rica, Dora Guzmán Zanetti, a través de la Ponencia de 30 de setiembre, difundió un primer proyecto, incluida una exposición de motivos, de reglas de imputación de responsabilidad penal a las personas jurídicas, en los siguientes términos:

"Artículo $1^{\circ}$.- Con excepción de los Poderes del Estado, las personas jurídicas de Derecho público o privado, son penalmente responsables por los delitos que cometan por medio de sus órganos legalmente competentes para decidir o actuar en su nombre.

Dicha responsabilidad es independiente de la responsabilidad penal y civil que personalmente pueda corresponder a los personeros que han concurrido a formar la voluntad social delictuosa.

159 Revista Canaria de Ciencias Penales. Monográfico 1/1999, p. 5. 
Son igualmente responsables los personeros que valiéndose de las atribuciones legales otorgadas por la persona jurídica, decidan o actúen ilícita e individualmente en el ejercicio de su representación.

Artículo $2^{\circ}$.- Las personas jurídicas tendrán acción penal y civil contra los personeros cuya decisión o actuación haya tenido como consecuencia el ilícito por el que se le sanciona y contra los miembros que debiendo oponerse al delito no lo hicieron.

Artículo $3^{\circ}$. - Las personas jurídicas que cometan los delitos tipificados en el Código Penal, serán sancionadas con las penas siguientes:

a) Disolución judicial, si el delito está sancionado con pena mínima de prisión de ... a más años;

b) Vigilancia judicial, cuando la pena máxima sea inferior a ... años de prisión;

c) Multa, por ... veces el monto extremo mayor fijado.

Artículo $4^{\circ}$.- Los delitos no comprendidos en el artículo anterior serán sancionados, según su gravedad, con: disolución judicial; vigilancia judicial; multa, o inhabilitación parcial o temporal de las actividades en que ocurrió el ilícito.

Artículo $5^{\circ}$.- Al aplicar la pena, el juzgador tomará en consideración, además de las circunstancias propias del hecho, las particulares del ente, tales como su antigiiedad, solvencia económica, prestigio social y comportamiento de sus órganos y personeros.

Artículo $6^{\circ}$.- Prescripción de las penas: ...

Artículo $7^{\circ}$. - Las normas generales señaladas en los títulos ... (del Código Penal Tipo) se aplicarán a los delitos en que incurran las personas jurídicas, en lo que fueren compatibles» ${ }^{160}$.

Este texto casi no fue objeto de discusión en aquella ocasión, de manera que en el III Encuentro de la Comisión Redactora del Código Penal Tipo Iberoamericano celebrado en Panamá del 26 al 30 de octubre de 1998, los comisionados Dora Guzmán Zanetti (Costa Rica), Renén Quiroz Pérez (Cuba) y José Zugaldía Espinar (España) presentaron una segunda propuesta de reglas de imputación de responsabilidad penal de las personas jurídicas, bajo la siguiente redacción:

160 Guzmán Zanetti. «Propuestas normativa sobre la responsabilidad penal de las personas jurídicas». En: Revista Canaria de Ciencias Penales. Monográfico 1/1999, pp. 219-222. También, con ligeras modificaciones, en: ADP 1996, pp. 187-189. 


$$
\text { «Título ... }
$$

De las personas penalmente responsables

Capítulo ...

De la responsabilidad penal de la persona jurídica

Artículo ...

1. Las personas jurídicas son penalmente responsables en los casos previstos por la Ley. Los entes públicos no son responsables más que de los delitos cometidos en el ejercicio de actividades susceptibles de ser desarrolladas también por los particulares.

2. La responsabilidad penal de las personas jurídicas no excluye la de las personas físicas autores o partícipes de los mismos hechos.

3. Los jueces y tribunales podrán imponer a las personas jurídicas las siguientes penas:

a) Disolución.

b) Clausura por tiempo no superior a cinco años

c) Suspensión total o parcial de actividades por tiempo no superior a cinco años.

d) La intervención judicial para no perjudicar los intereses de los trabajadores. Dicha intervención no podrá ser superior a cinco años.

e) Multa hasta el décuplo del beneficio obtenido por la actividad delictiva.

f) Caución de conducta.

g) El comiso de los instrumentos obtenidos con la infracción.

h) Pérdida de beneficios fiscales o de seguridad social.

i) Amonestación.

j) Publicación de la sentencian" ${ }^{161}$.

Tras un amplio debate en torno a los fundamentos de la responsabilidad penal de la propia persona jurídica, con la participación principal de los autores de la propuesta y los representantes José Hurtado Pozo (Perú), Esteban Righi (Argentina), Moisés Moreno Hernández (México), Francisco Dall'Anesse Ruiz (Costa Rica), Francisco Rodríguez Rojas (Colombia), Juan Manuel Fernández del Torco Alonso (España), Silvio Guerra Moráles (Panamá), José María Paz Rubio (España) y Manuel Jaén Vallejo (España) ${ }^{162}$, se aprobó este Proyecto, aunque se suprimió el

161 Revista Canaria de Ciencias Penales. Monográfico 1/1999, pp. 47, 178.

162 Ibid., pp. 85-102. 
mínimo de la multa que aparecía en el apartado e) ${ }^{163}$ por la gravedad que podía acarrear para la empresas de escaso patrimonio, y se dejó la determinación de los criterios de imputación para el próximo encuentro por no haberse alcanzado acuerdo al respecto ${ }^{164}$. En tal sentido, Hurtado Pozo propuso, entre los lineamientos a tener en cuenta para la IV Reunión que se proyectó realizar en México en 1999, que "Las penas referentes a las personas jurídicas deben ser reguladas considerando la índole peculiar de su responsabilidad y las consecuencias que provocarán respecto a sus miembros ajenos a la actividad delictuosa, a los trabajadores y a la comunidad» ${ }^{165}$, asimismo propuso adoptar las penas de disolución, clausura temporal, multa, intervención judicial temporal y publicación de la sentencia condenatoria ${ }^{166}$.

En el IV Encuentro de la Comisión, celebrado finalmente en Bogotá del 12 al 16 de marzo de 2001, en la sesión vespertina de 15 de marzo, tras la ponencia respectiva a cargo del representante peruano Carlos Caro, se acordó por unanimidad la revisión de los criterios adoptados en la III Reunión, a fin de resolver las siguientes cuestiones: 1) Los criterios de imputación de responsabilidad penal a la persona jurídica. 2) La extensión de la responsabilidad a las personas jurídicas irregulares o de hecho. 3) Los límites de la responsabilidad de los entes públicos. 4) La adopción de un sistema de numerus clausus en virtud del cual se precise específicamente en la Parte Especial en qué casos, frente a que delitos cabe la imposición de una pena al ente colectivo. 5) La revisión del sistema de sanciones a fin de incluir por ejemplo la prohibición temporal de contratar con la administración pública. 6) Los criterios de individualización judicial de la pena, en sentido estricto y en sentido amplio $^{167}$.

163 Se establecía como pena minima multa del triple del beneficio obtenido, Vid. Antonio José Cancino (dir). CP Tipo para Iberoamérica. Bogotá 2000, p. 120.

164 Revista Canaria de Ciencias Penales. Monográfico 1/1999, pp. 46, 102, $104-$ 105.

165 Hurtado Pozo. «Propuesta sobre el sistema de sanciones penales relativo al proyecto de CP Tipo Hispanoamericano". En: Revista Canaria de Ciencias Penales. Monográfico $1 / 1999$, p. 299.

166 Ibid., p. 303.

167 Caro Coria. "La responsabilidad penal de la propia persona jurídica". En: Antonio José Cancino (dir). DP Iberoamericano. Bogotá 2001, pp. 461y ss. 
De esta forma, se delegó al representante de Perú la redacción de una tercera propuesta de normas sobre la responsabilidad de los entes colectivos a fin de que se presente en el V Encuentro de la Comisión que se celebró en Culiacán/México del 11 al 15 de junio de 2001. En cumplimiento de ese encargo, teniendo especialmente en cuenta el modelo del Código Penal Francés de $1994^{168}$, el Anteproyecto Suizo de modificación del Código Penal ${ }^{169}$, el Corpus Iuris de 1996, la Ley Penal de Ambiente de Venezuela de 1992, el Art. $16^{\circ}$ del CP cubano, la Ley brasilera $\mathrm{N}^{\circ} 9.605$ de 12 de febrero de 1998 de delitos ambientales y el Art. $28^{\circ}$ del Anteproyecto de CP del Estado de Sinaloa/México, se puso a consideración la siguiente propuesta:

"Criterios de imputación de responsabilidad penal de las personas jurídicas

Artículo $1^{\circ}$.- Las personas jurídicas (y empresas) son penalmente responsables (en los casos expresamente previstos en la Ley,) por los delitos cometidos por quien obra en calidad de órgano o miembro de un órgano de dirección, por sus representantes o por quien dirige de hecho la persona jurídica. La responsabilidad penal de la persona jurídica no excluye la de las personas físicas autores o partícipes del mismo delito.

Si no es posible establecer quién cometió el delito o si este no puede ser atribuido a una persona determinada, la persona jurídica es penalmente responsable si la infracción puede ser imputada a un defecto de organización o a una administración deficiente del riesgo creado por ella.

Las personas jurídicas de derecho público responden penalmente cuando el delito se realiza en el ejercicio de una actividad o servicio público que puede ser desarrollado por particulares mediante contratos con el Estado.

Penas aplicables a las personas jurídicas

Artículo $2^{\circ}$.- Las personas jurídicas pueden ser sancionadas, de modo alternativo o acumulativo según establezca la ley, con las siguientes penas:

168 Aránguez Sánchez/Alarcón Navío. El CP francés. Traducido y anotado. Granada 2000. Desportes/Le Gunchec, “Las penas aplicables a las personas jurídicas». En: ADP 1997/1998, pp. 307ss.

169 Cit. por Du Puit. «La responsabilidad penal de las personas jurídicas en Suiza». En: ADP 1996, pp. 167-172. 
1. Amonestación.

2. Obligación de publicar la sentencia que declara la responsabilidad penal.

3. Comiso de los instrumentos que sirvieron para cometer el delito y de los beneficios obtenidos.

4. Multa de hasta el décuplo del beneficio obtenido o del daño creado por la actividad delictiva.

5. Pérdida de beneficios fiscales y subvenciones.

6. Prohibición por un periodo no mayor de cinco años de participar en las contrataciones públicas.

7. Vigilancia judicial por un periodo no mayor de cinco años de las actividades en cuyo ejercicio se cometió el hecho punible.

8. Intervención judicial por un periodo no mayor de cinco años a fin de cautelar los derechos de los trabajadores o de los acreedores.

9. Inhabilitación definitiva o temporal no mayor de cinco años para ejercer directa o indirectamente determinadas actividades profesionales o empresariales.

10. Clausura definitiva o temporal no mayor de cinco años de uno o más de los centros de trabajo o establecimientos que hayan servido para cometer el hecho delictivo.

11. Disolución cuando la persona jurídica ha sido creada para delinquir o cuando se utilice su organización para favorecer o encubrir hechos delictivos.

Las penas previstas en los numerales 10 y 11 no son aplicables a las personas jurídicas de derecho público.

Individualización judicial de la pena

Artículo $3^{\circ}$.- El Juez o Tribunal, al momento de individualizar la pena aplicable a la persona jurídica deberá tener en cuenta la gravedad de la infracción y la necesidad de prevenir la continuidad de la actividad delictiva. En el caso de penas que afectan el patrimonio de la persona jurídica, deberá tenerse en cuenta la capacidad económica de ésta.

Suspensión de la ejecución de las penas de disolución, clausura e inhabilitación

Artículo $4^{\circ}$.- La ejecución de las penas de disolución, clausura e inhabilitación previstas en los numerales 9, 10 y 11 del artículo 2, podrá suspenderse condicionalmente durante un periodo de prueba de tres a 
cinco años, sujeto al cumplimiento de reglas de conducta que permitan prever que la persona jurídica no cometerá nuevo delito. El Juez o Tribunal puede imponer una o más de las siguientes reglas de conducta:

1. Obligación de requerir autorización judicial para la realización de determinadas actividades.

2. Presentar periódicamente los estados contables auditados.

3. Informar periódicamente sobre las actividades de la persona jurídica. 4. Cumplir con el pago de la reparación civil.

5. Adoptar medidas para prevenir la comisión de infracciones de la misma naturaleza.

6. Las demás reglas que imponga el Juez o Tribunal de acuerdo a las circunstancias del hecho punible.

Si durante el periodo de prueba la persona jurídica incumple las reglas de conducta, el Juez o Tribunal podrá decretar, según el caso, la prolongación del periodo de prueba hasta por siete años, o la revocación de la suspensión de la ejecución de la pena. En este último caso, la pena impuesta se ejecutará conforme a la sentencia condenatoria. La suspensión de la ejecución de la pena será revocada si la persona jurídica es condenada por un nuevo delito.

Conversión de la pena de disolución

Artículo $5^{\circ}$.- Cuando no fuera procedente la suspensión de la ejecución de la pena de disolución prevista en el numeral 11 del artículo 2, podrá convertirse en una de clausura, inhabilitación o vigilancia judicial, según la gravedad de la infracción”.

Este planteamiento fue presentado y sometido a debate en la sesión matinal de 12 de junio, ocasión en la que el Secretario Perpetuo de la Comisión, Antonio Cancino, observó la propia decisión de criminalizar los "actos" de las personas jurídicas, debido a las dudas de constitucionalidad derivadas de una estigmatización por la conducta colectiva. En esa misma dirección, el representante alemán de Paraguay, Wolfgang Schöne, planteó la necesidad de limitar la imposición de la pena a las personas naturales, ello porque no quedaría claro el tratamiento de hechos delictivos adoptados de modo no unánime y cuya sanción podía acarrear consecuencias negativas inclusive para quienes, desde la perspectiva societaria, se opusieron a la resolución criminal. Asimismo, tampoco estaría claro el fundamento por el cual sería factible 
hacer responder a la persona jurídica por el comportamiento de sus representantes, además de no poderse superar fácilmente el problema del tipo de penas a imponer. De otra parte, el delegado mexicano Moisés Moreno expuso sus dudas desde la perspectiva de los criterios de imputación previstos en el Art. $1^{\circ}$ y su compatibilidad con el ordenamiento penal mexicano. Una valoración diferente motivó la intervención del representante panameño Silvio Guerra, para quien debía aún reflexionarse sobre la capacidad de acción y de penalización de las personas jurídicas, así como en relación al problema de los acuerdos delictivos no unánimes que se ejecutan.

Entre otras intervenciones de distinto sentido cuenta la del representante peruano Hurtado Pozo, quien sostuvo firmemente la necesidad de ratificar el acuerdo adoptado en el III Encuentro de la Comisión de 1998, consistente en admitir la necesidad de incorporar en el Proyecto de Código Penal Tipo Iberoamericano reglas de responsabilidad penal de las personas jurídicas. En esa perspectiva, Hurtado tuvo ocasión de presentar el estado actual de la discusión en el Derecho penal suizo y anglosajón, sistemas en los que prácticamente no se discute la adopción del societas delinquere potest pues se estima que la lucha contra la delincuencia económica requiere de la injerencia penal sobre los entes colectivos como medida político criminal fundada en un sistema dogmático distinto al que sustenta la responsabilidad penal de la persona humana.

En la sesión de 12 de junio de 2001 la Comisión no ratificó ni renunció al acuerdo de asumir la responsabilidad penal de los entes colectivos, habiendo decidido renovar la discusión en el VI Encuentro cuya realización se proyecta en Costa Rica en la segunda mitad del año 2002, lo que no sólo denota el fuerte arraigo al principio societas delinquere non potest en Iberoamérica, sino también una marcada reticencia a asumir que la persona jurídica realiza conductas penalmente relevantes y que por ello debe ser sancionada. Antes bien, Hurtado Pozo ha propuesto perfeccionar el proyecto que se debatió en México, considerando una redacción escueta como la siguiente, que aún requiere de mayores concreciones:

"Art. : La persona jurídica, sociedad o empresa individual será penada de acuerdo con el artículo ... [siguiente] por el delito cometido, en el ejercicio de sus actividades, por sus miembros y en la medida en que le fuera imputado en razón de un defecto de organización o una administración deficiente del riesgo creado por ella. 
Las personas físicas identificadas como responsables de la realización del delito serán penadas como autores o partícipes del mismo delito. Art. : A la persona jurídica, sociedad o empresa individual se le impondrán, alternativa o acumulativamente, las siguientes penas:

a...

b...

c...

El juez o tribunal, al individualizar la pena deberá tener en cuenta la gravedad del delito, la capacidad económica y la importancia del riesgo de que pueda dar lugar a la comisión de nuevos delitos» ${ }^{170}$.

En todo caso, habiéndose puesto en duda la propia asunción de la responsabilidad penal de las personas jurídicas, es de esperarse que el debate posterior se concentre en la revisión de los fundamentos dogmáticos y político criminales relativos a esta forma de responsabilidad ${ }^{171}$. Antes bien, teniendo en cuenta la proyección del Código Penal Tipo Iberoamericano como fuente de inspiración de la futura legislación penal de nuestros países, y ante la alarmante expansión de la criminalidad empresarial, es razonable esperar la adopción definitiva de reglas de imputación de consecuencias jurídicas contra los entes colectivos, lo que no necesariamente implica asumir un sistema de penas o medidas de seguridad, estando presente la opción de un modelo sui generis como el de las consecuencias accesorias del CP peruano de 1991 y del CP español de 1995.

170 Esta propuesta guarda similitud con el Art. $102^{\circ}$ del Proyecto de CP Suizo de

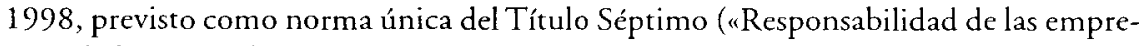
sas") de la PG, en los términos siguientes:

"Art. $102^{\circ}$

1 A través del funcionamiento de una empresa se puede realizar un hecho delictivo, y esa actividad delictiva puede no ser atribuible a una persona determinada por causa de una organización defectuosa de la empresa, entonces la empresa será sancionada con una multa de hasta 5 millones de Francos.

2 El Tribunal impondrá la multa de acuerdo a la gravedad del delito, el rendimiento económico de la empresa, así como el peligro de la comisión de nuevos delitos, de los que sería responsable la empresa.

3 Se consideran empresa de acuerdo al sentido de este artículo a las personas jurídicas, sociedades y firmas unipersonales."

171 Vid. Supra III. 


\subsection{La fórmula de la actuación «en lugar de otro»}

La fórmula del «actuar por otro", «en nombre de otro» o «en lugar de otro", se apreció por primera vez en el $\$ 14$ del StGB. Este planteamiento ha tenido acogida general en los sistemas penales iberoamericanos, en España a través primero del Art. $15^{\circ}$ bis del trCP y luego mediante el Art. $31^{\circ}$ del CP de 1995. En la misma dirección se incardinan el Art. $27^{\circ}$ del CP peruano de 1991, el Art. $38^{\circ}$ del CP de El Salvador de 1997, el Art. $29^{\circ}$ del CP Colombiano de $2000^{172}$ y el Art. $28^{\circ}$ del Anteproyecto de CP del Estado de Sinaloa/México. Más cercano a la postura del $\$ 14$ del StGB se encuentra el Art. $16^{\circ}$ del CP de Paraguay de $1997^{173}$.

Inicialmente esta cláusula fue valorada por un importante sector de la doctrina penal como el complemento necesario del societas delinquere

172 «Artículo $29^{\circ}$ - [...] También es autor quien actúa como miembro u órgano de representación autorizado o de hecho de una persona jurídica, de un ente colectivo sin tal atributo, o de una persona natural cuya representación voluntaria se detente, y realiza la conducta punible, aunque los elementos especiales que fundamentan la penalidad de la figura punible respectiva no concurran en él, pero sí en la persona o ente colectivo representado».

173 "Artículo $16^{\circ}$.- Actuación en representación de otro

1 La persona física que actuara como:

1. representante de una persona jurídica o como miembro de sus órganos;

2. socio apoderado de una sociedad de personas; o

3. representante legal de otro, responderá personalmente por el hecho punible, aunque no concurran en ella las condiciones, calidades o relaciones personales requeridas por el tipo penal, si tales circunstancias se dieran en la entidad o persona en cuyo nombre o representación obre.

$2^{\circ}$ Lo dispuesto en el inciso $1^{\circ}$ se aplicará también a la persona que, por parte del titular de un establecimiento o empresa, u otro con el poder correspondiente, haya sido:

1. nombrado como encargado del establecimiento o de la empresa; o

2. encargado en forma particular y expresa del cumplimiento, bajo responsabilidad propia, de determinadas obligaciones del titular,

y cuando en los casos previstos en ambos numerales, haya actuado en base a este encargo o mandato.

$3^{\circ}$ Lo dispuesto en el inciso $1^{\circ}$ se aplicará también a quien actuara en base a un mandato en el sentido del inciso $2^{\circ}$, numeral 1 , otorgado por una cntidad encargada de tareas de la administración pública.

$4^{\circ}$ Los incisos anteriores se aplicarán aun cuando careciera de validez el acto jurídico que debía fundamentar la capacidad de representación o el mandato». 
non potest, en el sentido de que el sistema de irresponsabilidad penal de la persona jurídica no debía redundar en la impunidad de las personas naturales que habían ostentado el dominio del hecho. En tal dirección, el «actuar en lugar de otro" vino a satisfacer un vacío de punibilidad que se observaba principalmente en los delitos especiales propios en los que no era posible imputar el hecho al ente colectivo, ni a los ejecutores materiales del mismo por la ausencia de la circunstancia que fundamenta el delito especial.

Esta perspectiva ha sido ampliada en los últimos años, partiéndose como aquí del presupuesto de que la posible punición de la persona jurídica no debe redundar en la impunidad de las personas naturales. De ese modo, la cláusula del "actuar en lugar de otro" no puede observarse como mera salida frente a un vacío de punición, sino quizás como el refuerzo necesario de la responsabilidad de las personas naturales en un sistema tributario del societas delinquere potest. En esa línea de ideas se inscribe la propuesta presentada por el Profesor Zugaldía en la III Reunión de la Comisión Redactora del Código Penal Tipo para Iberoamérica, en el siguiente sentido ${ }^{174}$ :

\section{«Título X}

De las personas penalmente responsables

\section{Capítulo XX}

De la actuación en nombre de otro

Art. B. El que actuare como administrador de hecho o de derecho de una persona jurídica, o en representación legal o voluntaria de otro, responderá personalmente aunque no concurran en él las circunstancias personales que la correspondiente figura del delito requiera para poder ser autor del mismo, si tales circunstancias se dan en la entidad o persona en cuyo nombre o representación obre.»

Esta importante formulación coincide sustancialmente con el sentido del Art. $31^{\circ}$ del CP español, norma que bien se encamina hacia una fundamentación material del instituto del "actuar en lugar de otro", como se aprecia por ejemplo tras la consideración de la administración 
de hecho. No obstante, como precisa Martínez-Buján Pérez, la norma hispana mantiene rezagos de la teoría formal de la representación adoptada por el Art. $15^{\circ}$ bis del trCP ${ }^{175}$. Y la tesis de la representación plantea problemas de punición en los siguientes grupos de $\operatorname{casos}^{176}: 1$ ) en los supuestos de representación fáctica donde se aprecia una actuación no autorizada, sin eficacia para efectos de la representación. 2) En los delitos de tendencias subjetivas egoístas, donde el tipo requiere por ejemplo la actuación «en provecho propio». 3) Cuando el representante no actúa a favor del representado sino en su propio interés. 4) Cuando el especial elemento de la autoría no lo ostenta el representado sino un tercero. 5) En las actuaciones a favor de grupos de empresas o empresas jurídicamente atomizadas en una pluralidad de sociedades individuales y con personería jurídica propia.

Es oportuno replantear los alcances de esta institución a fin de asumir una redacción más acorde con una postura material ${ }^{177}$, partiendo de propuestas como la de Schünemann en torno a la "posición de garante» del representante frente al bien jurídico-penal, o la teoría del «dominio social" esbozada por Gracia Martín que exige una relación de equivalencia material entre la conducta del "extraneus» y quien ostenta la cualidad especial. En esa orientación material, en cumplimiento del encargo asumido en la sesión de 15 de marzo de 2001 del IV Encuentro de la Comisión Redactora del Código Penal Tipo Iberoamericano, el representante peruano Carlos Caro presentó para la discusión en la sesión de 12 de junio de 2001 del V Encuentro, el siguiente texto que se basa en la propuesta de Meini Méndez de modificación del Art. $27^{\circ} \mathrm{del}$ $\mathrm{CP}$ peruano ${ }^{178}$, que además extiende la institución al caso de los delitos especiales impropios a fin de evitar "vacíos de agravación»:

175 Martínez-Buján. DP económico. PG, op. cit., p. 225.

176 Meini Méndez. "El “actuar en lugar de otro" en el DP peruano". En: NFP 62/ 1999, pp. 135-136.

177 No satisfecha plenamente, conforme a lo expuesto, en el Art. $31^{\circ}$ del CP español, norma que, pese a las múltiples críticas en la doctrina hispana, a juicio de Castillo Alva. «El actuar por otro: responsabilidad penal de los órganos representantes y socios representantes de una persona jurídica. El caso peruano». En: Normas Legales T. 279/1999, p. A-74, se erige como modelo a seguir por el ordenamiento peruano porque traería "una evidente fundamentación material".

178 Meini Méndez. "El "actuar en lugar de otro" en el DP peruano", op. cit., p. 150 . 
«Actuación en lugar de otro

Artículo $1^{\circ}$.- El representante legal o de hecho de una persona jurídica (, empresa) o de una persona natural que realiza un delito, será considerado como autor, aún cuando él o los elementos que fundamentan o agravan la pena, no concurran en él pero sí en la persona a quien representa, a pesar de que el hecho previsto como delito requiera la actuación en provecho propio y el agente no haya actuado con tal fin".

Este planteamiento no alcanzó a ser discutido en el marco del V Encuentro, de modo tal que, con los correctivos necesarios, se espera su aprobación en el VI Encuentro proyectado para fines de 2002, lo que seguramente no será problemático en tanto se estima que el presupuesto mínimo para la persecución de la criminalidad empresarial se cifra en el mejoramiento de las reglas de imputación de responsabilidad a las personas naturales en los delitos especiales. 